Universidade de Brasília

Centro de Excelência em Turismo

\title{
A UTILIZAÇÃO DA INTERNET COMO CANAL DE FORTALECIMENTO DO MARKETING ESTRATÉGICO NA HOTELARIA
}

Aluna: Fernanda Cristina Monteiro

Orientador: Gilson Zehetmeyer Borda

Brasília, DF, março de 2004. 


\section{A UTILIZAÇÃO DA INTERNET COMO CANAL DE FORTALECIMENTO DO MARKETING ESTRATÉGICO NA HOTELARIA}

Aluna: Fernanda Cristina Monteiro

Orientador: Gilson Zehetmeyer Borda

Monografia apresentada ao Centro de Excelência em Turismo da Universidade de Brasília como requisito parcial para a obtenção do certificado de Especialista em Gestão e Marketing do Turismo

Brasília, DF, março de 2004. 
UNIVERSIDADE DE BRASÍLIA

Centro de Excelência em Turismo

Curso de Especialização em Gestão e Marketing do Turismo

\title{
A UTILIZAÇÃO DA INTERNET COMO CANAL DE FORTALECIMENTO DO MARKETING ESTRATÉGICO NA HOTELARIA
}

\section{Fernanda Cristina Monteiro}

\author{
Banca Examinadora
}
Gilson Zehetmeyer Borda, titulação
Orientador

\author{
Nome, titulação \\ Membro da Banca
}

Brasília, DF, 22 de Março de 2004. 
Monteiro, Fernanda Cristina

A Utilização da Internet como canal de fortalecimento do marketing Estratégico na Hotelaria / Fernanda Cristina Monteiro 63 folhas

Monografia (Especialização em Gestão e marketing do Turismo) Universidade de Brasília. Centro de Excelência em Turismo. Brasília, 2004.

Área de concentração: Turismo

Orientador: Gilson Zehetmeyer Borda

1. Hotelaria 2. Marketing 3. Marketing Eletrônico 


\section{FERNANDA CRISTINA MONTEIRO}

\section{A Utilização da Internet como Canal de Fortalecimento} do Marketing Estratégico na Hotelaria

Comissão Avaliadora

Gilson Zehetmeyer Borda

Professor 1

Professor 2

Brasília, DF, 22 de março de 2004. 
Dedico este trabalho a minha mãe, Janilda Monteiro e a minha irmã, Danielle Monteiro, que estiveram durante todo o trabalho me incentivando e me encorajando a seguir sempre em frente. Elas participaram de cada conquista e cada dificuldade que tive durante a realização deste trabalho e serviram de apoio sempre que precisei. Indiretamente, esta monografia também é de vocês. 
Agradeço a todos aqueles que contribuíram para a realização deste trabalho. Ao meu orientador, professor Gilson, que mostrou através de suas dicas e correções os caminhos para a realização de mais este sonho.

Aos meus amigos, Thiago e Isabela, que com carinho e atenção, me ajudaram muito. 


\section{RESUMO}

Diante de um mercado cada vez mais competitivo, existe a necessidade dos hotéis estarem atentos a toda forma de inovação. A Internet, através de suas características peculiares, fornece ao setor hoteleiro diversas vantagens nesse sentido. É também uma tecnologia que possibilita aos hotéis criar o seu diferencial. Os hotéis podem se destacar no cenário turístico utilizando as ferramentas do marketing eletrônico - web site e e-mail - para interagir com seus clientes. É importante destacar que para o alcance de um bom resultado na aplicação das técnicas do marketing na Internet, é preciso considerá-las como um complemento às estratégias tradicionais do marketing e adequá-las umas às outras.

PALAVRAS-CHAVE:

Marketing Hoteleiro. Marketing Eletrônico. Relações com clientes. 


\begin{abstract}
In front of a crescent competitive labour market, there is the necessity of the hotels be always in touch with all kinds of innovations. The internet, with all its peculiarities, gives to the hotels many advantages. Furthermore, the internet let the hotels create their own differential. The hotels can put themselves on the tourism spotlight using the various types of internet's tools - web site and e-mail- to interact with their clients. It's important to assure that, in order to get a good result on the application of the marketing internet's techniques, it is necessary to considerate these techniques as accessories of the traditional marketing strategies and adequate them to each other.
\end{abstract}

KEYWORDS:

Hotels Marketing. Internet Marketing. Relation with customers. 


\section{SUMÁRIO}

CAPÍTULOS

\section{PÁGINA}

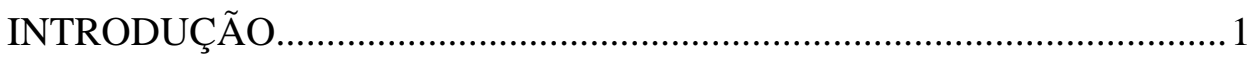

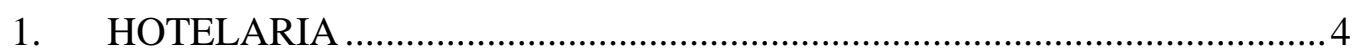

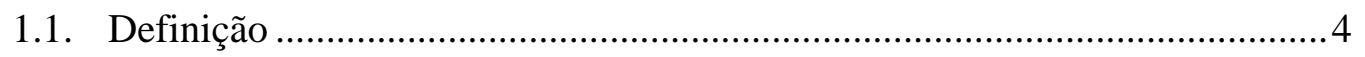

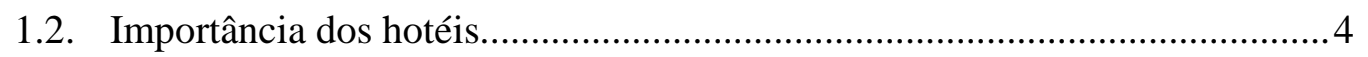

1.3. Características do produto hoteleiro.............................................................. 5

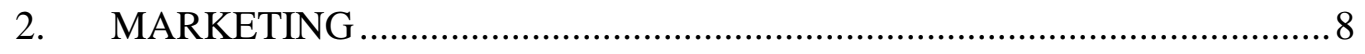

2.1. Gerenciamento de marketing.................................................................... 9

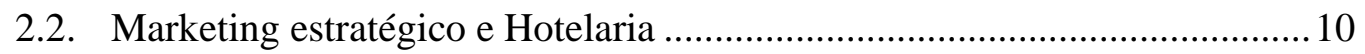

2.2.1. Princípios do planejamento estratégico ......................................................... 10

2.3. Marketing tático e Hotelaria....................................................................... 11

2.3.1. Inovações do Mix de Marketing ..................................................................19

2.4. Marketing interno e marketing de relacionamento na hotelaria...................19

2.4.1. Marketing Interno/ Endomarketing ..............................................................20

2.4.2. Marketing de Relacionamento...................................................................2 21

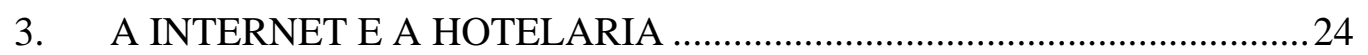

3.1. Definição e características da Internet voltada para o marketing..................24

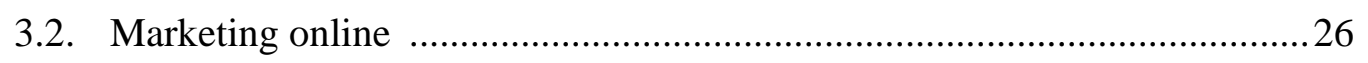

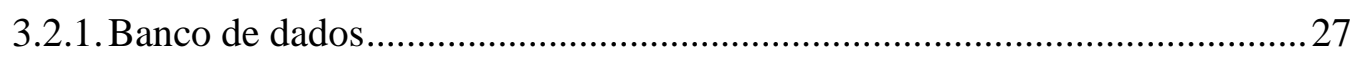

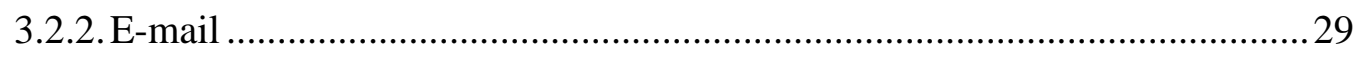

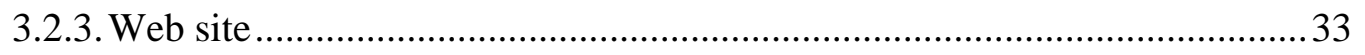

3.2.4. Aplicação das ferramentas de marketing on-line na hotelaria ....................... 35

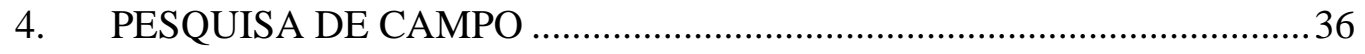

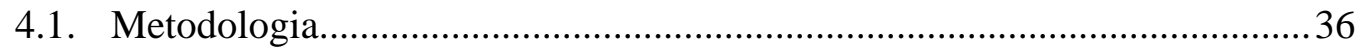

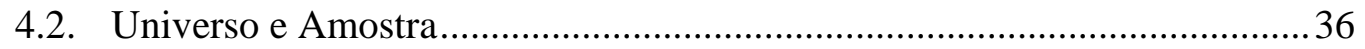

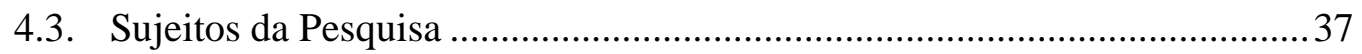




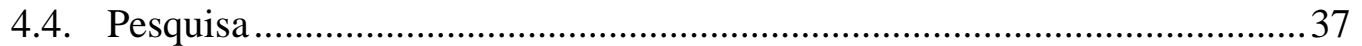

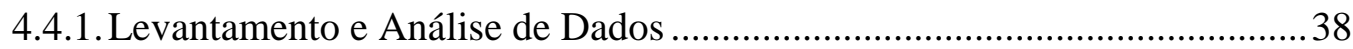

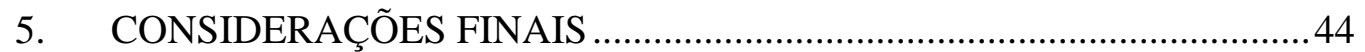

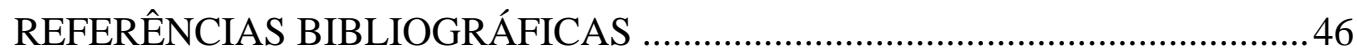

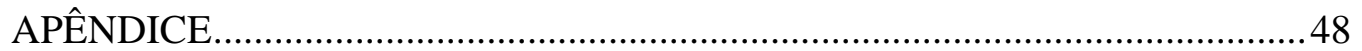




\section{LISTA DE FIGURAS}

\section{PÁGINA}

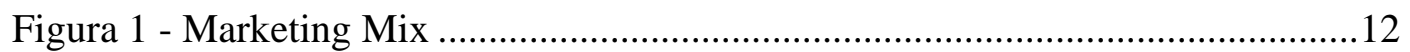

Figura 2 - Elasticidade de preço da demanda.........................................................14

Figura 3 - Mix de Marketing no Turismo e na Hotelaria ............................................18

\section{LISTA DE TABELAS}

Tabela 1 - Vantagens obtidas com o uso da Internet ............................................39

Tabela 2 - Desvantagens do uso da Internet..........................................................40

Tabela 3 - Formas de aplicação do marketing de relacionamento nos hotéis .............41

Tabela 4 - O uso do e-mail como ferramenta de marketing de relacionamento ........42 


\section{INTRODUÇÃO}

A oferta de bens denominados turísticos, colocados à disposição de consumidores potenciais, tem crescido, de acordo com Cobra (2001, p.2), para proporcionar cada vez mais a satisfação de necessidades de viagem, lazer e hospedagem, entre outros aspectos. E essa oferta tem-se tornado tão intensa e disputada que as organizações que operam no setor precisam estar aptas a enfrentar uma concorrência cada dia mais preparada.

Nesse cenário globalizado, as empresas de serviços precisam acompanhar a evolução tecnológica e o novo perfil de seus clientes efetivos e potenciais. E estes, por sua vez, têm exigido um atendimento personalizado e de alta qualidade que corresponda às suas expectativas.

Paralelamente a esse ambiente globalizado, a Internet vem avançando e invadindo todos os setores da sociedade. Seja na economia, na política, na educação ou por lazer, o uso da Internet cresce de forma intensa. As estatísticas sequer conseguem determinar com precisão o número de usuários devido ao crescimento acelerado.

No que se refere à economia e ao Marketing, a Internet tem demonstrado ser um instrumento com diversas aplicações. Pode ser usada como um meio de promoção, como um ambiente de contato com os diversos públicos, como instrumento de pesquisa, como agilizadora de processos administrativos, entre outros.

Diante disso, unir o turismo à Internet pode trazer muitos benefícios ao mercado turístico. Essa união pode gerar o diferencial que muitas empresas estão buscando para superar a concorrência.

A fim de encontrar novas estratégias de diferenciação, o presente estudo verifica a possibilidade de aplicação das ferramentas da Internet na hotelaria. A escolha da hotelaria se deve ao fato de ser um setor expressivo da cadeia turística. 
Diante da grandeza do assunto, delimitou-se a pesquisa às estratégias voltadas ao relacionamento dos hotéis com seus clientes, já que cresce a tendência do mercado de personalizar cada vez mais o seu atendimento.

O objetivo geral deste estudo é analisar se a Internet pode ser considerada como um instrumento para fortalecer o marketing estratégico do setor hoteleiro. Outro objetivo é a verificação de como o setor hoteleiro de Brasília tem utilizado a Internet para interagir com seus clientes. É, portanto, analisar se o relacionamento com clientes através da Internet é uma forma de fortalecer o marketing nos hotéis e como este aspecto é aplicado no setor hoteleiro de Brasília.

Afim de alcançar esses objetivos, os seguintes objetivos específicos foram almejados:

- Aprofundar os conhecimentos de marketing e relacioná-los com a hotelaria;

- Esclarecer as características e os objetivos do marketing eletrônico;

- Mostrar como o marketing eletrônico pode ser aplicado ao setor hoteleiro.

Para tanto, foram definidas as seguintes hipóteses:

1) A Internet é hoje um recurso valioso para as organizações hoteleiras.

2) Para os hotéis de Brasília, a Internet representa uma estratégia de interação com os clientes, além da redução de custos.

Para o desenvolvimento desse trabalho foram utilizadas duas formas de pesquisa: a pesquisa bibliográfica e a pesquisa de campo. A pesquisa bibliográfica foi dividida em dois estágios: o primeiro definindo os principais elementos do estudo, como hotelaria, marketing e marketing eletrônico; e o segundo fazendo uma interação entre esses elementos. Quanto à pesquisa de campo, foram selecionados hotéis de Brasília, de diversas categorias e realizadas entrevistas com a alta gerência a fim de descrever como a Internet está sendo utilizada no mercado hoteleiro e verificar se a Internet tem sido usada como meio de interação com 
clientes. Foi feita, também, uma análise do site de cada hotel, a fim de melhor identificar as técnicas utilizadas.

O trabalho está dividido em cinco capítulos. O primeiro refere-se às definições de hotelaria, a importância desse setor do turismo e as características no produto hoteleiro. O segundo capítulo envolveu os fundamentos do marketing e sua aplicação ao setor hoteleiro. No capítulo terceiro encontram-se as definições e características referentes à Internet, bem como, o marketing on-line e suas ferramentas. O capítulo quarto corresponde à pesquisa de campo, realizada no setor hoteleiro de Brasília, em que se verifica como os hotéis têm utilizado a Internet e suas ferramentas para melhor interagir com seus clientes. E, por fim, o capítulo cinco traz as considerações finais obtidas através de todo o estudo.

Como resultado deste trabalho pôde-se constatar, entre outras coisas, que:

1) A Internet é uma ferramenta valiosa e indispensável para o setor hoteleiro;

2) Na hotelaria, o uso da Internet é uma estratégia complementar às demais estratégias do marketing hoteleiro;

3) O uso da Internet pelos hotéis tem funções além da promoção e do comércio. Trata-se de um meio propício à estratégias de interação, personalização e retenção de clientes. 


\section{CAPÍTULO 1 - HOTELARIA}

\section{1 - Definição}

Hotelaria, em termos gerais, constitui um elemento básico do produto turístico, juntamente com transporte e atrativo. É, portanto, um subsistema do sistema de turismo ${ }^{1}$.

Anteriormente, a função de um hotel era acomodar aqueles que estão longe de casa e atender suas necessidades básicas. Medlik ${ }^{2}$ descreve um hotel como sendo "um estabelecimento que oferece hospedagem, alimentação e bebidas para os viajantes e residentes temporários e, freqüentemente, refeições e descanso, para outros tipos de usuários”.

Atualmente, o hotel não é mais visto exclusivamente como meio de hospedagem. Houve uma evolução no que se refere às atividades de um hotel. Para Petrocchi ${ }^{3}$, o hotel deixou de possuir somente espaços destinados a hospedar pessoas, para integrar-se ao seu entorno e oferecer espaços multifuncionais, voltando-se também para eventos empresariais e acontecimentos sociais. Assim, o hotel consiste em um empreendimento turístico cuja função principal é oferecer hospedagem e alimentação, podendo ainda, ser utilizado como local de realização de reuniões empresariais, seminários, palestras, etc; bem como, celebrações sociais.

\section{2 - Importância dos Hotéis}

Conforme o novo conceito de hotelaria desenvolvido por Petrocchi ${ }^{4}$, um hotel engloba uma grande variedade de serviços, o que o torna dependente do meio. Ele tanto influencia o local onde está situado como sofre influências externas. A instalação de um novo hotel estimula o crescimento local, gera novos empregos, entre outras coisas. No que se refere às influências externas, qualquer variação na economia, no clima ou no meio ambiente afetará

\footnotetext{
${ }^{1}$ PETROCCHI, Mário. Hotelaria - Planejamento e gestão. 2ed. São Paulo: Futura, 2002, p. 19.

${ }^{2}$ MEDLIK, S. e INGRAM, H. Introdução à hotelaria: Gerenciamento e serviços. 4ed. Rio de Janeiro: Campus, 2002, p. 04.

${ }^{3}$ PETROCCHI, Mário. Hotelaria - Planejamento e gestão. 2ed. São Paulo: Futura, 2002, p. 19.

${ }^{4}$ PETROCCHI, Mário. Hotelaria - Planejamento e gestão. 2ed. São Paulo: Futura, 2002, p. 19.
} 
diretamente na administração do hotel. Nota-se, portanto, que a sobrevivência de um hotel depende da sua capacidade de interagir com o meio.

Desse sistema de troca que um hotel necessita estabelecer com o meio, pode-se enumerar alguns pontos positivos de um empreendimento hoteleiro:

a. oferta de instalações para transações de negócios, reuniões e conferências, recreação e entretenimento.

b. contribuem de forma significativa para a economia local, tanto direta quanto indiretamente, através da difusão subseqüente de gastos de visitantes a outros receptores da comunidade.

c. importantes fontes de obtenção de moedas estrangeiras, se localizados em áreas que recebem estrangeiros.

d. são empregadores de mão-de-obra, contribuindo assim, para o desenvolvimento regional.

e. fonte de comodidade para os residentes locais, através de seus restaurantes, bares e outras instalações em geral.

\section{3 - Características do Produto Hoteleiro}

A hotelaria se encontra no mercado de serviços e como tal apresenta as características peculiares desse setor, tais como define Lara ${ }^{5}$ :

1. Intangibilidade: Os serviços são intangíveis porque não podem ser experimentados antes de serem comprados. Quem adquire um pacote turístico está adquirindo a promessa de uma viagem satisfatória. Os estabelecimentos devem tornar os seus

\footnotetext{
${ }^{5}$ LARA, Simone B. Marketing e venda na hotelaria. 2ed. São Paulo: Futura, 2001, p. 17.
} 
serviços os mais tangíveis possíveis disponibilizando o máximo de informações ao cliente. No caso dos hotéis, utilizar a própria infra-estrutura e o modo de atendimento como forma tangível de promover a imagem e o posicionamento. Ou seja, se o público-alvo do hotel são homens de negócios, é importante que o atendimento na recepção seja ágil, evitando a perda de tempo; utilização de equipamentos modernos; quartos equipados para o uso da Internet, etc. Não há uma ferramenta específica para tornar um serviço tangível, o importante é fazer com que o cliente se sinta seguro ao escolher o seu hotel ${ }^{6}$.

2. Inseparabilidade: $\mathrm{O}$ consumo do serviço de hospedagem é simultâneo à sua produção. Os serviços são inseparáveis daqueles que os fornecem. Não há como guardar e usar depois. Assim, é preciso considerar cada atendimento como único e muito importante, pois qualquer erro é percebido imediatamente pelo cliente e pode causar prejuízos irreparáveis.

3. Variabilidade: A qualidade dos serviços é basicamente fruto do desempenho humano e, portanto, de difícil padronização. O atendimento na recepção pode ser perfeito, mas, no restaurante, deixa a desejar; isso é o suficiente para não corresponder às expectativas do cliente.

Um bom trabalho de endomarketing que motive os funcionários e ofereça treinamentos periódicos pode reduzir os problemas da variabilidade.

4. Perecibilidade: Os serviços não podem ser estocados para venda futura. Terminado o dia, um quarto desocupado não pode mais gerar receita.

Dentro da perecibilidade pode-se abordar uma questão que afeta o setor hoteleiro - a sazonalidade - que de acordo com Cunha é:

\footnotetext{
${ }^{6}$ LARA, Simone B. Marketing e venda na hotelaria. 2ed. São Paulo: Futura, 2001, p. 17
} 
“A sazonalidade traduz-se pela distribuição da procura ao longo do ano de forma desigual, provocando uma concentração nuns meses mais do que em outros e deriva de fatores climatéricos, geográficos, demográficos, econômicos e psicosociais"?

Devido a diversos fatores como período de férias escolares e clima, os hotéis lotam em determinados períodos e praticamente param suas atividades em outros, trazendo problemas como a instabilidade do trabalho e a subutilização do hotel, nos períodos de pouca procura e, insatisfação dos hóspedes, nos períodos de superlotação. Dessa forma, é importante estar atento ao problema da sazonalidade. Dentre as possíveis soluções, encontram-se: a utilização de estratégias de promoção com tarifas mais baixas, a oferta de instalações para a realização de eventos e o investimento em turismo de negócios.

${ }^{7}$ CUNHA, Licínio. Economia e Política do Turismo. Lisboa: Mcgraw-Hill, 1997. p.189. 


\section{CAPÍTULO 2 - MARKETING}

O termo marketing já recebeu diversas definições. O marketing já foi confundido com vendas e já foi visto como atividade exclusivamente de promoção e propaganda. No entanto, esse tipo de abordagem não é mais aceita para organizações competitivas ou que querem destaque no mercado. De acordo com Silva ${ }^{8}$, “O marketing é muito mais do que incrementar vendas, é criar experiências marcantes para os clientes”.

“A visão de que uma indústria é um processo de satisfação de consumidores, e não um processo de produção de bens, é vital para todos os homens de negócios. Uma indústria começa com o consumidor e suas necessidades, não com uma patente, uma matéria-prima ou um talento para vendas ${ }^{9 » .}$. E isso é exatamente em que consistem as atividades de marketing.

Segundo Middleton ${ }^{10}$, o marketing é uma contribuição vital para a visão corporativa de futuro através de sua função de interpretar as necessidades dos clientes e as tendências do mercado no ambiente dos negócios externos à empresa”

Compreender e enxergar o marketing como uma atividade baseada nas necessidades dos clientes tem sido primordial para as empresas. No entanto, o conceito de que o marketing é o desenvolvimento de experiências marcantes para os clientes é bastante inovador. Como o objetivo deste estudo é abordar sobre novas ferramentas do marketing a fim de obter um diferencial de mercado, será adotado o conceito de Silva ${ }^{11}$, em que o marketing baseia-se não só nas necessidades dos clientes, como também, na tentativa de superá-las.

\footnotetext{
${ }^{8}$ SILVA, Carlos José. Marketing turístico. Apostila de aula da disciplina Teoria de marketing do Centro de Excelência em Turismo da Universidade de Brasília, 2003, p.03.

${ }^{9}$ LEVITT apud SILVA, Adriano. Marketing, que diabo é isso? Revista Exame, São Paulo, 1997.

${ }^{10}$ MIDDLETON, Victor T. C. Marketing de turismo - teoria e prática. 3ed. Rio de Janeiro: Campus, 2001.

${ }^{11}$ SILVA, Carlos José. Marketing turístico. Apostila de aula da disciplina Teoria de marketing do Centro de Excelência em Turismo da Universidade de Brasília, 2003, p.03.
} 


\section{1 - Gerenciamento de Marketing}

O objetivo principal do gerenciamento de marketing é posicionar, da melhor maneira possível, tanto a companhia em relação à concorrência, quanto seus produtos dentro dos mercados. Um produto bem situado permite que a organização consiga distinguir-se de seus concorrentes e construa, assim, uma vantagem competitiva. Estabelecer uma colocação adequada do empreendimento e suas ofertas no mercado requer uma série de tarefas ligadas a várias etapas do gerenciamento de marketing. Algumas destas etapas estão atreladas ao marketing estratégico, enquanto outras, ao marketing tático. A distinção entre o marketing estratégico e o tático, segundo Kotler ${ }^{12}$ está no fato do primeiro tratar das questões amplas e gerais da estrutura de marketing de uma empresa, enquanto o segundo se encarrega do detalhamento das ações de marketing para cada produto. O marketing estratégico cuida de planejar as metas e objetivos da empresa, a imagem e o posicionamento da marca, as estratégias e programas gerais da organização, bem como o orçamento para a realização do planejado. Ele é a base para que as táticas de marketing possam ser elaboradas. O marketing tático, baseado no que foi planejado anteriormente, vai definir como cada produto disputará cada mercado. A preocupação gira em torno do mix de marketing, também denominado "4Ps" (produto, preço, promoção e ponto de venda). "O primeiro engloba todo o negócio a longo prazo; o segundo engloba mercados e produtos específicos a curto prazo"13

A união entre os dois elementos gera o planejamento de marketing, e torna possível estabelecer uma estrutura comum para todas as atividades da organização.

A falta de planejamento poderá, em contrapartida, resultar em $^{14}$ :

- Não aproveitamento de novas oportunidades e mercados potenciais

- Vulnerabilidade às ações da concorrência, e conseqüente perda de fatias do mercado

- Problemas de demanda em baixa temporada

- Serviços de baixa qualidade

\footnotetext{
${ }^{12}$ KOTLER, Philip. Marketing para o século XXI. 9ed. São Paulo: Futura, 2001.

${ }^{13}$ MIDDLETON, Victor T. C. Marketing de turismo - teoria e prática. 3ed. Rio de Janeiro: Campus, 2001.

${ }^{14}$ COOPER, Chris. Turismo - Princípios e práticas. 2ed. Porto Alegre: Bookman, 2001, p. 411
} 
- Falta de identificação com os clientes

- Funcionários mal treinados e com atitudes contrárias à missão da empresa.

\section{2 - Marketing Estratégico e Hotelaria}

Conforme citado anteriormente, o planejamento estratégico se ocupa mais da empresa no longo prazo. Seu foco está menos nos detalhes das atividades de marketing e mais com as influências e oportunidades do ambiente externo. Sob esse aspecto, o marketing aplicado aos hotéis é semelhante às outras organizações.

\subsection{1 - Princípios do planejamento estratégico}

Todas as formas de planejamento estratégico visam responder as seguintes perguntas voltadas para o ambiente externo ${ }^{15}$ :

- Qual o objetivo da empresa?

- Que lugar ela ocupa agora na indústria e que espaços ela possui no mercado?

- Quais oportunidades estão surgindo em um mundo de mudanças, as quais poderia desenvolver e liderar?

- Onde se deseja que a organização esteja em cinco anos ou mais?

- Quais decisões tomar para chegar onde se almeja estar?

Para o desenvolvimento destas questões, Kotler ${ }^{16}$ sugere alguns passos do planejamento estratégico:

1. Definição da missão da empresa.

2. Definição dos objetivos e metas.

3. Planejamento do portifólio de negócios e produtos.

4. Planejamento de estratégias.

\footnotetext{
${ }^{15}$ Adaptado de: MIDDLETON, Victor T. C. Marketing de turismo - teoria e prática. Tradução por Fabíola de Carvalho S. Vasconcellos. $3^{\text {a }}$ ed. Rio de Janeiro: Ed. Campus, 2001.

${ }^{16}$ KOTLER, Philip. Princípios de marketing. Rio de Janeiro: Prentice-Hall, 1993, p.19.
} 


\section{3 - Marketing Tático e Hotelaria}

O marketing tático consiste, basicamente, no desenvolvimento do seu mix. Diz respeito às variáveis que envolvem desde a identificação das necessidades dos clientes até o desenvolvimento de produtos de valor percebido maior, com boa definição de preço, boa distribuição e promoção, destinado a um público específico.

O ponto de partida para o marketing tático é a definição do mercado-alvo. Um hotel, não pode ser tudo para todas as pessoas. É preciso que haja um equilíbrio entre os produtos oferecidos e as características e exigências do segmento de mercado.

A determinação adequada dos segmentos de mercado leva a uma melhor compreensão das características e necessidades do público a ser satisfeito e possibilita estar atento à concorrência.

"Para que a segmentação tenha sucesso, é necessário aplicar rigor intelectual nos procedimentos de segmentação. Quando um grupo-alvo é identificado, é prudente verificar se o segmento é: mensurável, acessível, substancial, sustentável, viável e defensável”. ${ }^{17}$

Definido o mercado-alvo, a próxima etapa é a elaboração do mix de marketing, que é formada pelos 4 Ps :

- Produto

- Preço

- Promoção

- Ponto de venda

${ }^{17}$ COOPER, Chris;FLETCHER, John; WANHILL, Stephen; GILBERT, David; SHEPHERD, Rebecca. Turismo: princípios e prática. 2 ed. Porto alegre: Bookman,2001, p. 424. 
Cada um por sua vez, abrange várias atividades, como demonstrado na figura abaixo:

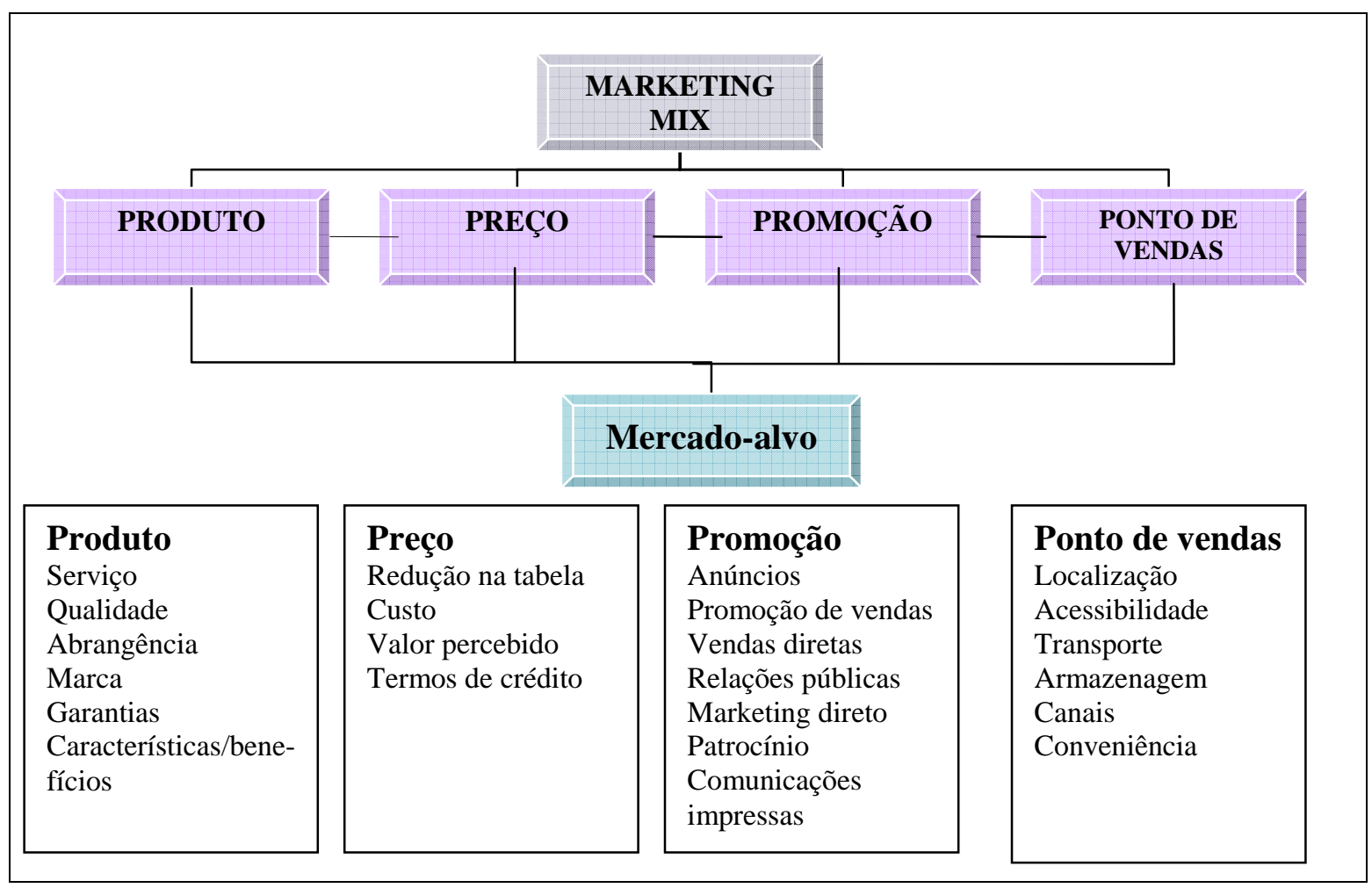

Figura 1 - Marketing mix

Fonte: COOPER, Chris. Turismo: princípios e prática, pág. 428.

\section{Produto}

Refere-se a "qualquer coisa que consiga satisfazer a uma necessidade"18.

“O produto hoteleiro reúne simultaneamente elementos tangíveis e intangíveis”. Como produto tangível tem-se a infra-estrutura do hotel, seu design e a ambiência, de modo geral. Os produtos intangíveis estão relacionados à qualidade no atendimento, ao grau de atenção pessoal, à velocidade, à eficiência e a tudo que possa gerar boas experiências para o cliente por meio do relacionamento cliente-hotel.

A hotelaria, por estar num contexto de serviço, apresenta produtos com características bem peculiares. A maioria dos autores aponta três características básicas:

\footnotetext{
${ }^{18}$ KOTLER, Philip. Marketing. São Paulo: Atlas, 1980, p. 31
} 
1. Intangibilidade: diz respeito ao fato de o produto não poder ser facilmente avaliado ou testado antes de sua aquisição.

2. Perecibilidade: significa que os serviços não podem ser estocados para venda futura.

3. Inseparabilidade: o produto é produzido e consumido simultaneamente. É, portanto, um produto vulnerável a variações na prestação. Cada vivência no hotel é única.

“A base de qualquer negócio é um produto ou serviço. Uma empresa tem por objetivo oferecer algo de maneira diferente e melhor, para que o mercado-alvo venha a preferi-lo e até mesmo pague um preço mais alto por ele”. ${ }^{19}$

\section{Preço}

Quanto a esse fator, o desenvolvimento do mix leva em consideração a relação entre a necessidade de lucro da empresa e a visão de valor que o consumidor tem do produto.

O sonho de qualquer empresário do turismo é poder estabelecer o preço que bem entender para seus produtos. Entretanto, um preço alto leva o comprador a procurar substitutos na concorrência, decretando o fracasso daquele produto.

Assim, estabelecer o preço certo é uma tarefa muito importante do marketing. No mercado turístico, o preço é afetado por diversos fatores e por isso precisa ser determinado analisando-se cada situação.

Dentre os fatores que interferem na decisão do preço nos empreendimentos turísticos estão ${ }^{20}$ :

- A sazonalidade da demanda

- A perecibilidade do produto

- As grandes diferenças de segmentos

\footnotetext{
${ }^{19}$ KOTLER, Philip. Marketing para o século XXI. 9 ed. São Paulo: Futura, 2001

${ }^{20}$ LAGE, Beatriz Helena e MILONE, Paulo César. Turismo: teoria e prática. São Paulo: Atlas, 2000, p. 33.
} 
- A competitividade

- Os consumidores (são os que definem o limite máximo dos preços adotados, uma vez que o mercado turístico é, no geral, sensível à renda dos consumidores)

- Os custos do empreendimento

- A situação econômica e política

A figura abaixo ilustra duas hipóteses de elasticidade de preço da demanda. O mercado turístico se identifica mais com a hipótese da direita, ou de uma demanda mais elástica. Em outras palavras, qualquer alteração de preço nos produtos turísticos pode acarretar grandes diferenças na demanda.

\section{Elasticidade de preço da demanda}

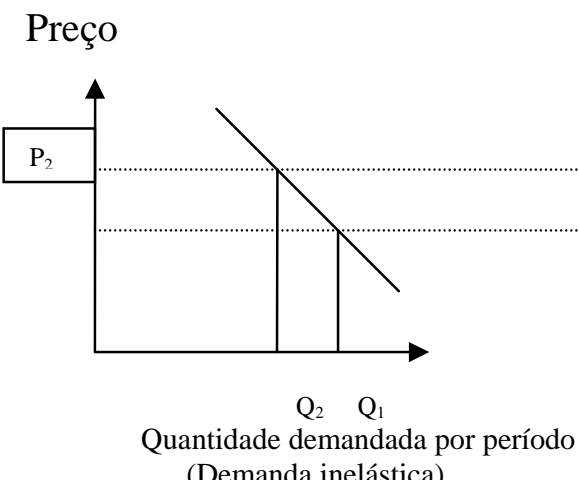
Preço

(Demanda inelástica)



Figura 2-Elasticidade de preço da demanda-Fonte: COOPER, Chris. Turismo: princípios e prática, pág. 433

Com o intento de selecionar o preço adequado, existem políticas a serem adotadas. Cooper $^{21}$ as divide em: definição de preço baseada em custo e definição de preço baseada na demanda (ou baseada no consumidor)

\footnotetext{
${ }^{21}$ COOPER, Chris. Turismo: princípios e prática. 2 ed. Porto Alegre: Bookman, 2001, p.435.
} 
Preço baseado em custo

Preço baseado na demanda Preço Discriminatório

Nos preços baseados em custo, o preço de Markup é estipulado em relação aos custos originais ou totais do produto. O preço de retorno-alvo, por sua vez, é calculado de acordo com uma taxa prevista de retorno do investimento.

Já nos preços baseados na demanda, o discriminatório ocorre quando produtos semelhantes são ofertados com diferentes preços, por causa de algum diferencial indireto. Exemplos dessa forma de preço são os quartos de hotéis, onde os que têm vista para o mar podem custar mais caro que os outros apesar de apresentarem as mesmas características.

Quanto ao preço de valor percebido, ele está voltado para o quanto o consumidor está disposto a pagar.

Nota-se, portanto, que a determinação de preço no setor hoteleiro merece análise cuidadosa e constante, pois a variação da demanda turística, bem como de outros fatores citados anteriormente, muitas vezes exige ajustamentos de curto prazo.

\section{Promoção}

Consiste nos métodos de comunicação do produto para o público-alvo. Serve para influenciar os consumidores, conquistar fatias de mercado, solidificar uma marca ou lançar um novo serviço.

As principais ferramentas de promoção são: 
- Propaganda: “A propaganda é a ferramenta mais poderosa para promover a conscientização das pessoas sobre uma empresa, um produto, um serviço ou uma idéia”. 22

- Promoção de vendas: São maneiras de conquistar o cliente através de brindes ou incentivos não comuns ao produto. Tem duração curta e resultados rápidos ${ }^{23}$

- Relações Públicas: “desenvolvimento de boas relações com os vários públicos da empresa pela obtenção de publicidade favorável, construção de uma "imagem corporativa" e o manuseio ou afastamento de rumores, histórias ou eventos desfavoráveis"24

- Merchandising: “é uma forma importante de estimular a compra por impulso ou de lembrar o consumidor do que está sendo oferecido”. ${ }^{25}$ Um exemplo para os hotéis é a utilização de anúncios de mesa e cartazes, nas agências de viagem ou no próprio estabelecimento, estimulando as vendas.

- Marketing direto: "São ações que visam à venda direta de produtos e serviços por parte da empresa. Utiliza-se de mala direta, folder, Internet, telemarketing, etc. $^{26}$

\section{Pontos de venda (Distribuição)}

É uma forma de disponibilização do produto. "É o canal utilizado para ganhar acesso aos compradores potenciais do produto ou serviço". ${ }^{27}$

\footnotetext{
${ }^{22}$ KOTLER, Philip. Marketing para o século XXI. 9 ed. São Paulo: Futura, 2001

${ }^{23}$ KUAZAQUI, Edmir. Marketing Turístico e de hospitalidade. São Paulo: Makron Books,2000, p. 128

${ }^{24}$ KOTLER, Philip e ARMSTRONG, Gary. Princípios de marketing. Rio de Janeiro: Prentice-Hall, 1993, p.288.

${ }^{25}$ COOPER, Chris. Turismo: princípios e prática. 2 ed. Porto Alegre: Bookman, 2001, p. 441

${ }^{26}$ KUAZAQUI, Edmir. Marketing Turístico e de hospitalidade. São Paulo: Makron Books, 2000, p.196

${ }^{27}$ COOPER, Chris. Turismo: princípios e prática. 2 ed. Porto Alegre: Bookman, 2001, p. 443
} 
No entanto, na hotelaria, por ser um produto turístico, a distribuição apresenta características especiais. Por se tratar de um serviço em que a produção e o consumo se realizam no mesmo ato, o produto turístico não sofre qualquer transferência de propriedade. Nesse sentido, uma preocupação do ponto de venda é quanto à localização do empreendimento turístico. Um hotel bem localizado é capaz de atrair uma demanda maior.

Alguns canais podem ser utilizados pelos hotéis a fim de alcançar os consumidores ${ }^{28}$ :

- Mala direta

- Ofertas em revista e jornais

- Telemarketing

- Eventos promocionais

- Internet

Dando destaque à Internet, por ser objeto desse estudo, têm-se utilizado sistemas de reservas como forma de distribuição eletrônica. A Internet tem sido vista como uma forma de ampliar os canais de venda e de baratear os custo de distribuição.

${ }^{28}$ LARA, Simone. Marketing e vendas na hotelaria 2ed. São Paulo: Futura, 2001, p. 91. 
Exemplo de aplicação do mix de marketing no turismo e na hotelaria

\begin{tabular}{|c|c|c|c|c|}
\hline & & HOTÉIS & $\begin{array}{l}\text { COMPANHIAS } \\
\text { AÉREAS }\end{array}$ & MUSEUS \\
\hline \multirow[t]{4}{*}{ PRODUTO } & $\begin{array}{l}\text { CARACTERÍSTICAS } \\
\text { DESENVOLVIDAS }\end{array}$ & $\begin{array}{l}\text { Localização } \\
\text { Tamanho do edifício } \\
\text { Design } \\
\text { Tamanho do quarto } \\
\text { Decoração } \\
\text { Ambiente } \\
\text { Iluminação } \\
\text { Estilos dos serviços de } \\
\text { alimentação }\end{array}$ & $\begin{array}{l}\text { Rotas } \\
\text { Serviços } \\
\text { Freqüência } \\
\text { Tipo de Aeronave } \\
\text { Espaço } \\
\text { Ambiente } \\
\text { Refeições } \\
\text { Estilo }\end{array}$ & $\begin{array}{l}\text { Tamanho do Edifício } \\
\text { Design } \\
\text { Tipo de Coleção } \\
\text { Tamanho da } \\
\text { Exibição } \\
\text { Interior }\end{array}$ \\
\hline & $\begin{array}{l}\text { COMPONENTE } \\
\text { SERVIÇO }\end{array}$ & \multicolumn{3}{|c|}{$\begin{array}{l}\text { Número de funcionários } \\
\text { Uniformes } \\
\text { Atitudes } \\
\text { Receptividades dos clientes }\end{array}$} \\
\hline & MARCA & Ex: Holiday Inn, Marriot & $\begin{array}{l}\text { Ex: American Airlines, } \\
\text { Varig, TAM }\end{array}$ & $\begin{array}{l}\text { Ex: Tate Gallery } \\
\text { (Londres) }\end{array}$ \\
\hline & POSIÇÃO & $\begin{array}{l}\text { Ex: Mercado para alto/ } \\
\text { baixo poder aquisitivo }\end{array}$ & $\begin{array}{l}\text { Ex: Confiável, Mal } \\
\text { gerenciada }\end{array}$ & $\begin{array}{l}\text { Ex: Tedioso, } \\
\text { Excitante, Moderno }\end{array}$ \\
\hline \multirow[t]{3}{*}{ PREÇO } & \multirow[t]{3}{*}{$\begin{array}{l}\text { PREÇO NORMAL/ PREÇO } \\
\text { PROMOCIONAL (Para cada } \\
\text { produto oferecido) }\end{array}$} & $\begin{array}{l}\text { Tarifas corporativas } \\
\text { Tarifas básicas }\end{array}$ & $\begin{array}{l}\text { Tarifas de grupo } \\
\text { Primeira classe/ } \\
\text { Executiva/ Class e } \\
\text { Turística }\end{array}$ & $\begin{array}{l}\text { Tarifa de adulto, } \\
\text { idoso, criança }\end{array}$ \\
\hline & & $\begin{array}{l}\text { Tarifas de usuários com } \\
\text { privilégio }\end{array}$ & Afretamento & Tarifa de grupo \\
\hline & & $\begin{array}{l}\text { Tarifas com desconto da } \\
\text { operadora }\end{array}$ & Tarifas Consolidadas & \\
\hline PROMOÇÃO & $\begin{array}{l}\text { PROPAGANDA } \\
\text { PROMOÇÃO DE VENDAS } \\
\text { RELAÇÕES PÚBLICAS } \\
\text { EQUIPE DE VENDAS }\end{array}$ & \multicolumn{3}{|c|}{ Exemplos específicos de cada organização } \\
\hline $\begin{array}{l}\text { PONTO DE } \\
\text { VENDAS }\end{array}$ & CANAIS DE DISTRIBUIÇÃO & $\begin{array}{l}\text { Sistemas de reservas } \\
\text { computadorizadas } \\
\text { Internet } \\
\text { Agentes de viagens } \\
\text { Operadoras } \\
\text { Linhas de telefone gratuitas }\end{array}$ & $\begin{array}{l}\text { Sistemas de reservas } \\
\text { computadorizadas } \\
\text { Internet } \\
\text { Escritórios na cidade } \\
\\
\text { Balcões no Aeroporto } \\
\text { Ligações } 0800\end{array}$ & $\begin{array}{l}\text { Outros Museus } \\
\text { Internet } \\
\text { Agências de } \\
\text { informações } \\
\text { turísticas } \\
\text { Recepção de Hotéis }\end{array}$ \\
\hline
\end{tabular}

Figura 3 - Mix de marketing no turismo e na hotelaria - Fonte: MIDDLETON, Victor. Marketing de turismo 


\subsection{1 - Inovações do Mix de Marketing}

Segundo alguns autores a estrutura dos 4 Ps de marketing é apropriada para a indústria manufatureira, porém é incompleta no que se refere aos serviços. Tal idéia está baseada nas características do mercado de serviços. Neste, ocorre uma inseparabilidade entre os processos de produção e consumo, em que estes dois se confundem, ao contrário do que acontece no mercado de bens físicos. Seguindo este raciocínio, tem-se que os consumidores são partes integrantes e participativas do processo. Com isso nota-se que o papel do marketing no ambiente de serviços é acrescido do gerenciamento das relações entre a empresa e seus clientes, geradas da interação entre os processos de produção e consumo. Disso decorre a necessidade que alguns autores têm de adotar os 3 Ps adicionais sugeridos por Booms e Bitner $^{29}$, quando se referem ao mercado de serviços:

- Pessoas

- Processos

- Evidências físicas (physical evidences)

A hotelaria recepciona, de forma bastante clara, os 3Ps adicionais, pois a maioria de suas atividades está focada na participação dos clientes no processo de produção dos serviços. A importância de somar esses novos elementos ao mix de marketing hoteleiro se deve ao fato de que essa interação com o cliente no processo de produção do serviço influenciará diretamente no valor percebido pelo cliente do serviço como um todo.

\section{4 - Marketing Interno e Marketing de Relacionamento na Hotelaria}

Estabelecer e aplicar técnicas de marketing são requisitos indispensáveis a todo e qualquer empreendimento. Na hotelaria, no entanto, há que se destacar a necessidade da aplicação do marketing interno e do marketing de relacionamento. Todo hotel que se fundamenta no marketing se preocupa com a satisfação dos desejos dos seus clientes ou até mesmo em superar as expectativas destes. O marketing de relacionamento é um dos meios que

\footnotetext{
${ }^{29}$ BOOMS, B. H. e BITNER, M. J. apud GRÖNROOS, Christian. Marketing - Gerenciamento e serviços. Rio de Janeiro: Campus, 2003, p. 298.
} 
contribui para o alcance dessa meta. E como satisfazer os clientes se, internamente, os funcionários não estão satisfeitos?

\subsection{1 - Marketing interno / Endomarketing}

O termo marketing interno ou endomarketing sugere a definição: aplicação do marketing dentro da empresa. De fato, esse é um dos aspectos do marketing interno, mas há ainda outros fatores importantes.

Segundo Gronroos ${ }^{30}$, o endomarketing é um conceito do tipo "guarda-chuva” para uma gama de atividades internas, cujo objetivo é desenvolver uma orientação para os serviços e para o cliente, e ainda, desenvolver um interesse no marketing entre os funcionários. Para ele, os empregados constituem o primeiro mercado para a organização.

Bekin $^{31}$ afirma que o endomarketing consiste em ações de marketing voltadas para o público interno da empresa, com o fim de promover entre seus funcionários e departamentos, valores destinados a servir o cliente. O comprometimento implica a adesão aos valores e objetivos da empresa e pressupõe o trabalho em equipe, num contexto marcado pela cooperação e pela integração dos vários setores da empresa. As informações sobre as atividades, projetos e metas devem ser antes divulgadas internamente, envolvendo maior número de funcionários para que se atinja um alto nível de participação nos diversos escalões da empresa.

Assim, o endomarketing é um conjunto de atividades humanas dirigidas para atender às necessidades dos públicos interno e externo e da organização. É treinar o público interno para que este tenha condições de repassar ao público externo tudo aquilo que a empresa possui de melhor e o que está aprimorando.

\footnotetext{
${ }^{30}$ GRONROOS, Christian. Marketing gerenciamento e serviços, São Paulo: Campus, 1995, p.279.

${ }^{31}$ BEKIN, Saul Faingauss. Conversando sobre endomarketing. Um ciclo de entrevistas com Saul Bekin. São Paulo: Makron Books Brasil, 1995.
} 
No setor hoteleiro a necessidade de aplicação do marketing interno é fundamental, pois a satisfação do cliente está diretamente relacionada com a satisfação do funcionário dentro da empresa. E, para isso, é importante observar se o funcionário recebe treinamentos regulares, se os gerentes dão suporte e apoio, se existe uma boa comunicação interna, enfim, se o funcionário é visto como um instrumento de ligação com os clientes e não apenas um cumpridor de tarefas. Portanto, treinamento, apoio gerencial, comunicação interna fluente são atividades do marketing interno que valorizam e estimulam os funcionários, gerando um melhor atendimento aos clientes.

Outro fator abordado pelo marketing interno e que tem grande importância na hotelaria, é permitir a participação dos funcionários na implantação de novas idéias. Nos hotéis, o contato entre funcionários e clientes é constante, o que possibilita que aqueles sejam os primeiros a detectar o que mais agrada determinados tipos de clientes, se o novo modo de atendimento sugerido pelo gerente realmente exerce um efeito positivo, quais são os problemas mais freqüentes, etc. Assim, o funcionário como grande detentor de informações pode contribuir para determinar qual a melhor solução de um problema.

Portanto, a empresa hoteleira deve treinar e motivar eficazmente seus funcionários, além de orientá-los para a satisfação das necessidades dos clientes, a fim de proporcionar um bom atendimento.

\subsection{2- Marketing de Relacionamento}

O marketing de relacionamento parte do princípio de que o conhecimento e o relacionamento com os clientes são fundamentais para o sucesso das organizações. Segundo o Nykamp Consulting Group, marketing de relacionamento significa "otimizar todos os contatos com os clientes”. (Nykamp Consulting Group apud Organização Mundial de Turismo, 2003) ${ }^{32}$. Para fundamentar seu conceito, apresenta um modelo de marketing de relacionamento dividido em 4 etapas:

\footnotetext{
${ }^{32}$ ORGANIZAÇÃO MUNDIAL DE TURISMO. E-business para turismo, Porto Alegre: Bookman, 2001, p. 24
} 
1. Compreensão das necessidades dos clientes e diferenciação com base nas necessidades, nas características e no comportamento dos clientes;

2. Desenvolvimento de produtos, serviços e canais, além da personalização a diferentes segmentos;

3. Interação com os clientes

4. Aquisição e retenção de clientes

Para Petrocchi ${ }^{33}$, o marketing de relacionamento é “a busca de preservação do cliente, alcançando um nível elevado de atendimento e incentivando a repetição da compra, através de estímulos de bonificação e tratamentos diferenciados”. Estabelece, também, que o marketing de relacionamento deve basear-se em vantagens financeiras ao cliente, no tratamento diferenciado, na estruturação de cadastros de clientes e em uma comunicação eficaz com os clientes.

As empresas hoteleiras, com suas características específicas de serviços, têm sua sobrevivência ligada diretamente ao seu relacionamento com os hóspedes. Por isso, a forma e a qualidade do relacionamento devem ser bem planejadas. Tais estratégias possibilitam tanto a conquista como a manutenção dos clientes. O sucesso do hotel pode ser alcançado e mantido com um bom trabalho de manutenção dos clientes já existentes, pois essa estratégia gera repetidas hospedagens ao longo da vida do cliente, uma vez que este está satisfeito e identifica o hotel com sendo um espaço seu.

Dessa forma, dar atenção à qualidade do atendimento, perceber a importância de cada contato que o hóspede tem com o hotel, buscar novas formas de manter o relacionamento com o cliente (mala direta, telemarketing, website, e-mail) são estratégias que devem ser valorizadas para que um empreendimento hoteleiro se destaque no mercado.

Assim, o marketing nos hotéis deve obedecer a premissa de que os clientes são o ponto de partida de todas as ações do hotel e de que além de satisfazer as necessidades dos clientes o hotel deve tornar sua estada um evento único. É importante também que todas as etapas do plano de marketing sejam cumpridas:

\footnotetext{
${ }^{33}$ PETROCCHI, Mário. Hotelaria - Planejamento e gestão. 2 ed. São Paulo: Futura, 2002, p. 82
} 


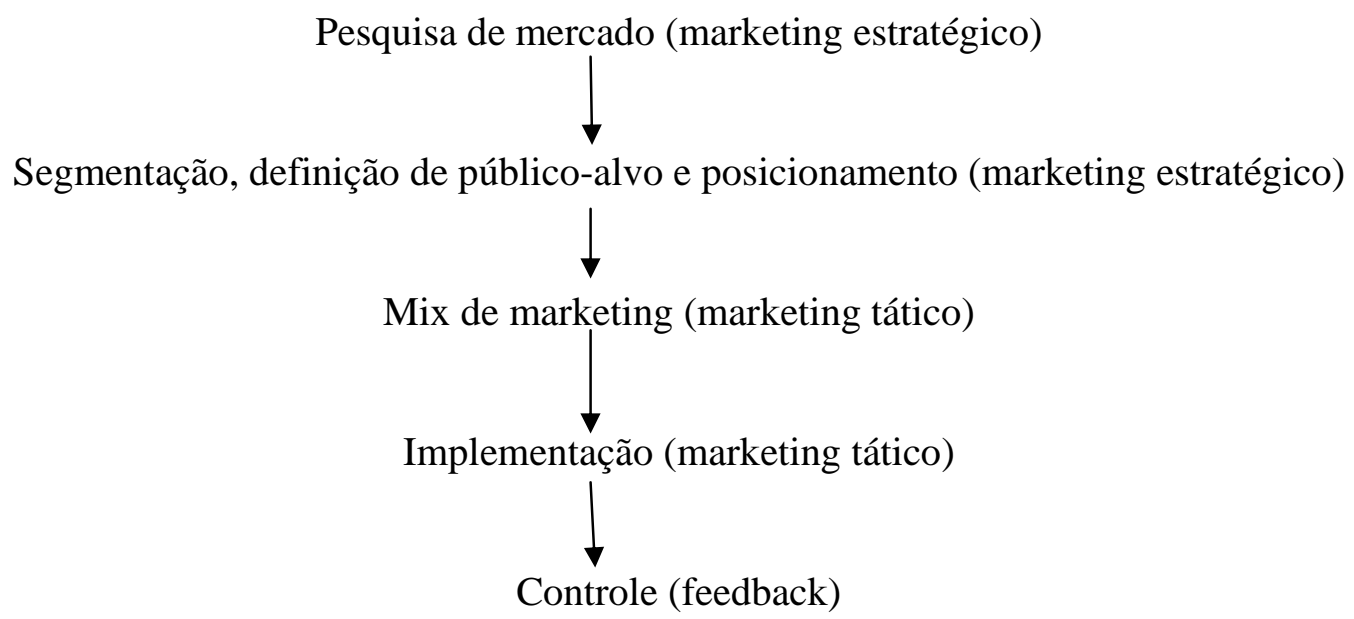

A pesquisa de mercado, bem como a segmentação, a definição do público e o posicionamento são atividades referentes ao hotel como um todo e que servem de base para o bom desempenho do mix de marketing. Este, por sua vez, está diretamente relacionado ao produto, preço, praça e promoção. Nos hotéis, o produto se subdivide em tangíveis e intangíveis, o que valoriza o cuidado que se deve ter com o atendimento ao cliente. No que se refere ao preço destaca-se a importância do valor percebido pelo cliente, pois determinará e influenciará as questões da demanda. Praça (ou ponto de venda), no ambiente hoteleiro está muito relacionada com o próprio local do empreendimento, visto que a produção do serviço e o seu consumo são simultâneos. Quanto à promoção, os hotéis têm utilizado os métodos tradicionais, como a propaganda, o marketing direto e as relações públicas. A utilização das atividades de endomarketing e de marketing de relacionamento também fazem parte do marketing hoteleiro, já que a hotelaria é um ramo especialmente de contato com o público. Além disso, o hotel, como pertencente ao mercado de serviço, deve incorporar aos 4Ps tradicionais do marketing os 3Ps adicionais (pessoas, processos e physical evidence) dando importância ao gerenciamento das relações entre empresa e clientes. 


\section{CAPÍTULO 3 - A INTERNET E A HOTELARIA}

Para vencer a concorrência, uma empresa precisa estar atenta às novas tendências do mercado, atualizada com as novas tecnologias e com o comportamento dos seus clientes efetivos e potenciais. Ter bons equipamentos e uma infra-estrutura de qualidade é importante, mas o que faz a diferença competitiva no mercado é a capacidade que a companhia tem de captar, armazenar e explorar tanto as informações internas quanto as informações do ambiente externo.

Na hotelaria, o fluxo de dados e a qualidade das informações são essenciais para a sobrevivência do negócio. O trabalho é todo baseado no relacionamento com o cliente. Assim, é importante que a informação flua rápida e precisamente entre o consumidor e a empresa. Esse cenário faz com que a utilização da Internet seja substancial para o setor hoteleiro.

Basta comparar um hotel equipado com sistema de reservas on-line, website com todas as informações sobre preços, acomodações e promoções, atendimento ao cliente on-line, a outro que não possui tais artifícios. Qual deles é capaz de captar mais clientes? Qual está mais propenso a satisfazer as expectativas dos usuários?

\section{1 - Definição e Características da Internet voltadas para o Marketing}

Do ponto de vista do marketing, a Internet constitui um importante e novo canal de distribuição que fornecem aos profissionais de marketing um meio poderoso e direto pelo qual interagir com os consumidores (Murphy, 1996 apud O’Connor, 2001).

A Internet apresenta diversas características que permitem inovar as aplicações do marketing tradicional. Seu alcance global é uma de suas mais importantes características. Ao colocar uma informação de sua empresa na web, ela estará disponível aos clientes potenciais de todo o mundo, 24 horas por dia. Qualquer cliente terá acesso ao material promocional da empresa sempre que precisar sem a necessidade de contatar o pessoal de vendas no horário 
comercial. Tem-se, portanto, maior disponibilidade de informações e promoção com menor custo.

Na web, a promoção pode ser feita com recursos de fotografia e ilustrações em todas as cores, bem como, sons, animação e vídeo com um custo inferior aos meios tradicionais. E, ainda, uma propaganda na web pode ser atualizada ou modificada rapidamente, permitindo a promoção de ofertas de última hora.

No que se refere ao consumidor, os papéis são invertidos. O cliente é quem tem o controle e não o profissional de marketing, uma vez que aqueles determinam o que irão ver, quando, qual a direção e a ordem na qual a informação será apresentada ${ }^{34}$. Assim, nota-se que os clientes na Internet são inteiramente ativos e controladores.

Como visto no parágrafo anterior, é o consumidor quem busca as informações. Tem-se, portanto, mais uma vantagem sobre o marketing tradicional - o acesso facilitado aos futuros possíveis clientes. Através da Internet a empresa tem acesso às pessoas interessadas em seus produtos, uma vez que estas estão buscando informações relacionadas a eles.

A Internet apresenta, ainda, uma característica muito importante para a aplicação do marketing que é a contribuição para o processo de personalização. Além do potencial de seleção de clientes, a Internet possibilita a comunicação em duas vias ${ }^{35}$. Essa característica faz da Internet uma importante ferramenta para o marketing de relacionamento e para a construção da fidelidade do cliente.

Conforme as características expostas acima, a utilização da Internet pode oferecer as seguintes vantagens para uma empresa:

- Aumentar a visibilidade

- Reduzir os custos

- Expandir seus mercados

\footnotetext{
${ }^{34}$ O’CONNOR, Peter. Distribuição da informação eletrônica em Turismo e Hotelaria. Porto Alegre: Bookman, 2001, p. 107.

${ }^{35}$ idem
} 
- Melhorar o atendimento dos clientes

- Satisfazer as expectativas de seus clientes

- Melhorar o programa de fidelização

\section{2 - Marketing On-line}

"Marketing on-line é um processo destinado a vender produtos e serviços para um público-alvo que utiliza a Internet e sistemas de informação on-line, mediante a adoção de ferramentas e serviços on-line de uma maneira estratégica e coerente com o programa de marketing global da empresa”36. Assim, o marketing on-line é uma ramificação do marketing aplicado a esse novo mercado que é a Internet.

Conforme o conceito acima, dois aspectos devem ser respeitados na utilização do marketing on-line: a adequação do marketing às características da Internet e a integração do marketing on-line ao programa de marketing da empresa. Quanto ao primeiro, destaca-se a importância da utilização de estratégias destinadas a um mercado com características peculiares. Usar estratégias do marketing tradicional não trará bons resultados, pois o públicoalvo tem um papel ativo e controlador, diferente do que acontece no marketing tradicional; o ambiente é interativo; a propaganda persuasiva não é aceita pelos usuários; entre outras características.

O segundo aspecto diz respeito à necessidade de englobar as ações do marketing on-line ao restante das atividades de marketing utilizadas pelo hotel. O marketing on-line funciona como mais uma estratégia de marketing adotada pela empresa para se diferenciar no mercado e não como um substituto do marketing até então usado. Assim, é importante que ao optar por utilizar ferramentas de marketing on-line, a organização, primeiramente, as integrem com o restante das atividades de marketing do empreendimento.

O marketing on-line pode ser utilizado com diversas finalidades, como vendas, propaganda e relacionamento com clientes. A hotelaria admite todas essas funções, no entanto,

\footnotetext{
${ }^{36}$ JANAL, Daniel. Como fazer marketing na Internet. 2ed. Rio de Janeiro: infobook, 1996, p. 18
} 
a utilização do marketing on-line voltado para o relacionamento com os clientes é a finalidade mais inovadora para os hotéis, pois a sobrevivência dos hotéis depende do contato com o cliente.

O marketing on-line fornece ferramentas que permitem uma melhor interação empresacliente:

1. Banco de dados

2. E-mail

3. Website

\subsection{1 - Banco de Dados}

De acordo com $\mathrm{NASH}^{37}$, banco de dados do ponto de vista mercadológico “consiste na compilação de nomes e endereços de clientes individuais e potenciais para o objetivo de comunicar informações, pelo correio ou pelo telefone, resultando direta ou indiretamente em vendas e lucros”. Explica ainda que, o database marketing combina os elementos do marketing direto, da publicidade e da promoção de vendas, de forma integrada, tornando-se uma ferramenta de maior eficiência. O banco de dados, como instrumento mercadológico, possibilita que a empresa conheça mais os seus clientes; e em decorrência disso permite que a publicidade e a promoção sejam melhor direcionadas.

Existem duas formas de uma empresa obter um banco de dados: construindo o seu próprio banco de dados ou comprando uma lista. Nash afirma que o banco de dados mais valioso e fácil de ser obtido é a lista de seus próprios clientes. Tal importância se deve ao fato: de a conservação de um cliente atual custar menos do que ganhar um novo; de, muitas vezes, ser mais proveitoso aumentar o consumo dos clientes atuais ou negociar com eles do que com novos clientes; e de os atuais clientes, presumivelmente satisfeitos, terem maiores possibilidades de ser os responsáveis pela extensão da linha ou de produtos novos, mediante o uso do nome da marca em que eles aprenderam a confiar.

\footnotetext{
${ }^{37}$ NASH, Edward. Database marketing: Ferramenta atual e decisiva do marketing. São Paulo: Makron Books, 1994, p.02
} 
Uma vez que possua uma lista de clientes, é importante ajustá-la às demais ferramentas de marketing, pois o banco de dados servirá de base para todas as ações promocionais da empresa. Através do banco de dados a empresa terá como obter a informação ideal para a elaboração de uma mala direta ou de um programa de telemarketing bem sucedido, por exemplo.

Com a grande concorrência, o mercado tem exigido um atendimento mais individualizado e diferenciado. Nesse sentido, surge uma necessidade de aumentar e segmentar a lista, visto que um maior número de informações possibilita maiores chances das ações de marketing atingirem o sucesso. "A segmentação de mercado permite ao profissional de marketing reconhecer necessidades e interesses não atendidos que possam representar uma oportunidade lucrativa no mercado"38.

Os tipos de segmentação mais usados na hotelaria, de acordo com LARA ${ }^{39}$, são:

- Segmentação por benefícios - Busca agrupar os clientes que buscam benefícios similares, como por exemplo, preços baixos, localização, luxo das instalações ou alta excelência no atendimento.

- Segmentação demográfica - Agrupa pessoas que tenham características comuns, como cidadãos da terceira idade com alto poder aquisitivo.

- Segmentação por ocasião - agrupa pessoas de acordo com as ocasiões de utilização de um produto/serviço, ou seja, negócios e lazer.

NASH acrescenta a esses tipos de segmentação, a categorização - em que os clientes são classificados em diferentes categorias. A fórmula clássica utilizada é a RFP ("R” refere-se a clientes recentes ou atuais, " $F$ " a compradores freqüentes ou de muitas compras e "P" simboliza a categoria do preço).

Os hotéis tanto podem optar por atuar em apenas um segmento como também utilizar uma segmentação múltipla. No entanto, se a empresa visa uma estratégia de relacionamento

\footnotetext{
${ }^{38}$ LARA, Simone. Marketing e vendas na hotelaria. 2ed. São Paulo: Futura, 2001.

39 idem
} 
com seus clientes, optar por nichos de mercado tem trazido bons resultados. "Concentrar-se em atender determinado nicho traz a vantagem de conhecer melhor cada cliente, percebendo mudanças de atitudes rapidamente, enfrentando assim, de forma melhor, a concorrência, e atingindo altas margens de lucro, já que os clientes geralmente estão dispostos a pagar mais para quem os conhece e atende melhor”(LARA, 2001).

Por fim, é essencial que haja uma manutenção do banco de dados da empresa. Possuir um banco de dados não é acumular informações, mas ter a informação necessária para ações de marketing. Ferramentas como questionários on-line, telemarketing e promoções são maneiras de se obter e atualizar informações precisas à empresa. Entretanto, algumas cadeias de hotéis têm enriquecido seus bancos de dados não apenas com a utilização de ferramentas de marketing, mas também com as informações resultantes do contato com o cliente, observando quem solicitou ou não uma sala para reunião, que shows pagos foram assistidos na televisão, ou que drinques foram encomendados no salão do hotel, entre outros.

Assim, o banco de dados tem sido um instrumento basal para as outras ações de marketing. É através dele que são adquiridas as informações a serem utilizadas, por exemplo, na estruturação de uma nova forma de interagir com os clientes.

\subsection{2 - E-mail}

“O correio eletrônico, ou e-mail, é o veículo básico para se alcançarem grupos específicos de consumidores e interagir com eles nos sistemas on-line”. ${ }^{40}$ Ao contrário do que acontece com a mídia televisiva, de jornais e revistas, em que há uma comunicação de massa, o e-mail tem a capacidade de atingir pequenos grupos ou, até mesmo, realizar o marketing um a um, sendo assim, essencial para o desenvolvimento de uma relação sólida com os clientes.

O e-mail tem, ainda, as vantagens de ser barato e rápido ${ }^{41}$. Barato no sentido de não haver custo com produção em papel ou postagem; seu principal gasto é com as empresas

\footnotetext{
40 JANAL, Daniel. Como fazer marketing na Internet. 2ed. Rio de Janeiro: Infobook, 1996, p.215.

${ }^{41}$ STERNE, Jim. E-mail marketing, São Paulo: Makron Books, 2002, p.03.
} 
provedoras de e-mail. Rápido, por fazer parte do ambiente on-line, onde a troca de informações independe de horário comercial, além do fato de que mensagens certas para o público certo tendem a acelerar todo o processo.

Através do e-mail, é possível estabelecer um diálogo contínuo com o público-alvo, obter respostas sem invadir a privacidade do consumidor e, principalmente, modificar ações e planos de marketing em tempo real, afirma Mohrisk, presidente da empresa Peppers \& Rogers ${ }^{42}$.

Existem outras funções do e-mail a serem utilizadas pelo departamento de marketing, como por exemplo ${ }^{43}$ :

- Sondar novos segmentos do mercado, apresentando o seu produto ou serviço ao cliente.

- Transformar consumidores eventuais em clientes, fornecendo-lhes as informações requisitadas, com o histórico da sua empresa, press-releases, dados técnicos sobre seus produtos, relatórios, pesquisas e resenhas.

- Estabelecer relacionamentos duradouros e conquistar fidelidade à sua marca, mantendo os consumidores informados sobre novos produtos e serviços, liquidações, descontos, eventos especiais, etc.

- Conduzir pesquisas de mercado analisando as mensagens dos consumidores.

O primeiro passo na utilização do $e$-mail é divulgar o seu endereço eletrônico em todo o seu material de promoção - papel timbrado da empresa, envelopes, bloco de anotações, pressreleases, anúncios e folhetos. Para se tornar uma nova forma de comunicação é preciso que seu público conheça o seu endereço de $e$-mail.

Respeitar as regras do ambiente on-line é um fator importante para o sucesso na utilização dessa ferramenta. Por se tratar de um ambiente de fácil distribuição de mensagens, muitas empresas tendem a usar o e-mail para uma distribuição, em massa, de anúncios

\footnotetext{
${ }^{42}$ ARAUJO, Anna Gabriela. Artigo atração on-line, Revista Marketing, p.24.

${ }^{43}$ JANAL, Daniel. Como fazer marketing na Internet. 2ed. Rio de Janeiro: Infobook, 1996, p.216.
} 
persuasivos, como é feito no marketing tradicional. Segundo JANAL e STERNE, esse não é o melhor caminho. O correio eletrônico deve ser um meio interativo de troca de informações, em que o destinatário tenha autorizado o envio de tais informações ao seu endereço de $e$-mail.

\section{REGRAS PARA MENSAGENS DE E-MAIL}

1. Seja comercial somente nos lugares apropriados: A propaganda não é permitida na maioria das áreas de mensagens. Se você quiser postar um anúncio, lembre-se de fazêlo somente nas áreas apropriadas, como um newsgroup dedicado a anúncios classificados para a venda. É lícito anunciar produtos e serviços em alguns fóruns ${ }^{44} \mathrm{e}$ newsgroups ${ }^{45}$ criados especialmente para este fim.

2. Seja politicamente correto: Não insulte as pessoas fazendo comentários sobre sua idade, sexo, estado civil, religião ou orientação sexual.

3. Seja polido: As mensagens de e-mail, mesmo contra a vontade de seus autores, às vezes podem parecer um pouco ríspidas. Certos comentários podem parecer cáusticos, e uma piada pode ser entendida como uma crítica, pois o destinatário não tem como visualizar as suas expressões faciais ou ouvir a entonação da sua voz. Assim, seja polido ao extremo. Se tiver de pecar, faça-o pelo excesso de zelo. Assuma que tudo o que pode parecer negativo será compreendido desta forma.

4. Seja breve: A comunicação on-line tende a ser resumida. Muitas formalidades da correspondência tradicional - como cabeçalhos, saudações e fechos - não são utilizados. Empregue sentenças curtas e diretas, e procure não estender suas mensagens por mais de uma tela.

5. Seja gramaticalmente correto

\footnotetext{
${ }^{44}$ Fórum é um misto de biblioteca e área destinada à troca de mensagens nos sistemas de informações. Pode ser para o uso de todos os usuários do serviço de informação ou exclusivo de assinantes. Trata-se se um veículo em que as empresas podem colocar seus press-releases, relatórios de lucratividade, anúncios de novos produtos, oferecer prévias de novos produtos e serviços, vender produtos, etc.

${ }^{45}$ Newsgroups é um grupo de pessoas no ambiente on-line que discutem e trocam informações sobre assuntos específicos e semelhantes.
} 
6. Seja discreto: NÃO DIGITE EM LETRAS MAIÚSCULAS. Se fizer isso, parecerá estar gritando.

7. Seja específico: Os títulos podem atrair ou afastar os leitores das suas mensagens. "Preciso de ajuda para criar anúncios" é bem melhor do que simplesmente "Preciso de ajuda”.

8. Seja objetivo: não se afaste do assunto. Se na linha do assunto está escrito “café”, não responda com uma mensagem sobre o seu restaurante predileto. Deixe para fazer isso quando o assunto o permitir.

9. Seja conciso: Quando responder a uma mensagem, reproduza a parte dela à qual a resposta se refere; isto ajudará o destinatário - que provavelmente recebe muitas mensagens - a recordar do que você está falando. Ao fazer isso, contudo, não inclua toda a mensagem original, mas somente uma linha ou trecho relevante.

10.Seja generoso: Contribua com a comunidade. Responda às dúvidas e aos pedidos de ajuda. Procedendo desta forma, você se tornará uma parte bem aceita do grupo. Isto o ajudará a adquirir credibilidade, o que facilitará a tarefa de promover o seu próprio negócio de uma maneira não-invasiva.

11.Seja "singular": Não poste a mesma mensagem duas vezes no mesmo fórum. Existem razões pessoais e técnicas para isso. As pessoas não gostam de receber mensagens repetitivas, especialmente se estiverem pagando pelo tempo de conexão ou por cada mensagem recebida. Como motivo técnico, é importante lembrar que o espaço das áreas de mensagens é limitado; quando ele se esgota, as mensagens mais antigas são removidas, e no lugar delas entram novas. Assim, se postar muitas mensagens desnecessariamente, você poderá acabar removendo mensagens que poderiam ser úteis para as outras pessoas.

12.Seja honesto: Obedeça às regras para anunciar nos fóruns e siga os princípios de etiqueta. Práticas com esquemas de pirâmides e especulação com ações são tão ilegais no ambiente on-line como em qualquer outra mídia. 
13.Seja você mesmo: Use o seu nome verdadeiro, e não um apelido. As pessoas merecem saber com quem estão falando.

14.Seja informativo: As pessoas gostam de ler informações, e não anúncios, quando estão conectadas a um serviço on-line.

15.Seja bem-informado: Leia as mensagens dos outros usuários durante algum tempo antes de começar a participar ativamente das discussões. Leia os arquivos de "help" e FAQS (Questões freqüentes), a fim de descobrir como o sistema funciona e o que é ou não permitido fazer.

(Janal, 1996, pág. 83)

Assim, no programa de interação da empresa com os seus clientes, o e-mail poderá ser utilizado de diversas maneiras. Numa estratégia de retenção de clientes, algumas empresas utilizam o e-mail apenas para demonstrar ao cliente que não os esqueceu, enviando-lhes um boletim, uma oferta de desconto ou um lembrete. Usar o e-mail como um veículo de atendimento ao cliente é outra estratégia. Pode-se também, usar o e-mail estimulando os clientes a conhecer o site da empresa. Ações de Relações Públicas podem ser realizadas através do e-mail. O e-mail é, portanto, uma ferramenta fundamental para o gerenciamento da relação com os clientes.

\subsection{3 - Web Site}

Muito se fala da utilização de web sites para a comercialização de produtos e serviços no ambiente on-line, no entanto, um site na Internet pode ser, também, mais uma forma de interagir com os clientes de uma empresa.

Segundo JIM STERNE, “a world wide web é uma nova mídia de comunicação”46. É, portanto, mais uma forma da empresa mostrar-se no mercado. Ter um site significa ter mais

\footnotetext{
${ }^{46}$ STERNE, Jim. Marketing na web - Integrando a web à sua estratégia de marketing, 2 ed. Rio de Janeiro: Campus, 2000, p.42.
} 
um local de divulgação da empresa, de promoção e comercialização de seus produtos e serviços, e também, de relacionamento com seu público-alvo.

Em um site, o marketing de relacionamento pode ser desempenhado através das seguintes técnicas de marketing eletrônico ${ }^{47}$ :

1. Quadro de avisos eletrônicos e salas de bate-papo:

Essa técnica possibilita a criação de uma comunidade on-line em seu site, em que os usuários poderão conversar entre si e responder questões sobre assuntos específicos. Através dessa técnica a empresa terá acesso aos dados de futuros clientes, uma vez que para participar das discussões terão que se registrar. Outra vantagem é a possibilidade de conhecer, indiretamente, as necessidades dos usuários.

2. Clubes on-line:

Muitos sites oferecem uma chance ao usuário para ser membro de um clube especial que oferece benefícios extras, como o aviso antecipado sobre ofertas, notícias e agilidade em reservas.

3. Formulários de avaliação:

A empresa poderá solicitar aos usuários que avaliem sua visita ao site. O formulário deverá ser simples, curto. Os dados obtidos deverão ser armazenados no banco de dados de clientes.

4. Suporte ao cliente:

Essa técnica põe à disposição dos usuários um canal direto com um profissional da empresa capaz de responder às suas dúvidas.

${ }^{47}$ ORGANIZAÇÃO MUNDIAL DE TURISMO. E-business para turismo. Porto Alegre: Bookman, 2003. 


\subsection{4 - Aplicação das Ferramentas do marketing On-line na Hotelaria}

Na hotelaria, o uso das técnicas do marketing on-line é inovador para uma diferenciação da empresa no mercado. A utilização do banco de dados no setor hoteleiro não é nenhuma novidade. A novidade é que, com a Internet foram criadas novas maneiras de obtenção e manutenção dos dados. E, tendo em vista que, quanto maior e mais apurado for esse banco de dados, mais chances têm a empresa de desenvolver produtos e serviços que atendam a necessidades ou interesses específicos, o setor hoteleiro terá maiores possibilidades de ser mais lucrativo. Outra vantagem do uso do banco de dados através da Internet para os hotéis é o rápido acesso e controle dos dados do cliente.

Quanto ao uso do e-mail pelos hotéis, têm-se um novo canal de interação com os clientes. Seja para realização de reservas ou para o envio de folheto do hotel, o e-mail é um intensificador do contato com os clientes.

A web é outra ferramenta da Internet que tem muito a contribuir ao setor hoteleiro. "O hotel pode marcar presença na web de diversas maneiras, como oferecer informações, promover debates, oferecer treinamentos e fazer comércio eletrônico”. ${ }^{4}$

Nota-se, portanto, que direta ou indiretamente, todas essas ferramentas da Internet contribuem para uma melhor interação dos hotéis com seus clientes, pois todas possibilitam um acesso maior de dados dos clientes, o que possibilita um atendimento mais individualizado, e conseqüentemente, a retenção e a fidelização desses clientes.

\footnotetext{
${ }^{48}$ LARA, Simone. Marketing e vendas na hotelaria, 2ed. São Paulo: Futura, 2001, p. 130.
} 


\section{CAPÍTULO 4 - PESQUISA DE CAMPO}

\section{1 - Metodologia}

Em complemento a parte teórica do trabalho, o projeto apresenta uma pesquisa de campo, realizada na cidade de Brasília, que teve o intuito de analisar a efetiva utilização das principais ferramentas de marketing eletrônico dentro do setor hoteleiro, no que se refere ao relacionamento com a clientela.

Esta é uma pesquisa de caráter qualitativo e que tem como objetivo a exploração e a descrição. Qualitativa, já que inexiste a preocupação de enumeração, de medição, nem do emprego de meios estatísticos para a análise dos dados. Exploratória no sentido de que não existem muitos estudos sobre a utilização do marketing digital no setor hoteleiro de Brasília. É, ainda, descritiva porque visa descrever como o setor hoteleiro de Brasília utiliza as ferramentas de marketing digital e assim reconhecer problemas ou oportunidades referentes a esse estudo.

O método de abordagem será o hipotético-dedutivo, tendo em vista que serão verificadas as hipóteses de que a utilização de ferramentas do marketing eletrônico representa um diferencial para as organizações hoteleiras de Brasília.

\section{2 - Universo e Amostra}

O universo da pesquisa são 24 hotéis, detentores de endereço de e-mail e de website e classificados de duas a quatro estrelas. A fonte para a definição do universo foi o Guia Quatro Rodas - Brasil 2004, uma publicação conceituada e respeitada no meio turístico.

A amostra foi definida pelo critério da acessibilidade ${ }^{49}$, sendo composta por 13 hotéis.

\footnotetext{
${ }^{49}$ VERGARA, Sylvia Constant. Projetos e relatórios de pesquisa em Administração, 4ed. São Paulo: Atlas, 2003, p.51.
} 


\section{3 - Sujeitos da Pesquisa}

Segundo Vergara, os sujeitos de uma pesquisa são as pessoas que fornecem os dados da pesquisa. Assim, os sujeitos da pesquisa foram os gerentes responsáveis pelas atividades de marketing de cada hotel escolhido.

\section{4 - Pesquisa}

A pesquisa foi realizada através de entrevistas com os gerentes responsáveis pelas ações de marketing. Anteriormente à execução das entrevistas, foi enviada a cada hotel uma carta de apresentação da pesquisa, em que constavam os objetivos, uma breve justificativa, uma autorização para a realização da entrevista e, ainda, disponibilizava os resultados, caso houvesse interesse.

Segue o modelo da carta enviada: 
Brasília, 02 de março de 2004.

Ao Sr.

Gerente

Hotel

Boa tarde,

Meu Nome é Fernanda Monteiro, sou aluna do Centro de Excelência em Turismo, da UnB e estou fazendo um estudo sobre o uso da Internet no setor hoteleiro, com o objetivo de encontrar a melhor forma de utilização desse meio pelos hotéis, do ponto de vista do marketing.

A pesquisa enfoca, principalmente, o uso da Internet no marketing de relacionamento com os clientes, tendo em vista que para o setor hoteleiro quanto mais interagir com os clientes melhor poderá ser o seu atendimento.

Com essa pesquisa pretendo obter uma visão geral do uso dessa nova tecnologia no setor hoteleiro de Brasília e posteriormente propor novas estratégias de marketing para hotéis.

Para isso estou fazendo um levantamento nos hotéis de Brasília, através de entrevista com os responsáveis pelo setor de marketing dos hotéis. Gostaria de saber se posso contar com a sua colaboração e incluir o Hotel a nessa pesquisa.

Ao final do estudo, caso haja interesse, estarei disponibilizando uma cópia das conclusões obtidas através da pesquisa, podendo assim contribuir para o desenvolvimento de novas estratégias para o setor hoteleiro.

Aguardo uma resposta para que possamos agendar o melhor horário.

Obrigado

Fernanda Monteiro

Tel. de contato:

A entrevista foi baseada em algumas perguntas previamente estabelecidas, com o intuito de focalizar, exclusivamente, no assunto desejado.

\subsection{1 - Levantamento e Análise de Dados}

Entre as finalidades que os hotéis estão buscando ao adotarem a Internet como estratégia de marketing, constatou que: $100 \%$ dos entrevistados utilizam a Internet como meio de promoção; 84,6\% para vendas/ reservas; 38,4\% como forma de reduzir os custos e apenas $30,7 \%$ a usa para interagir com seus clientes. Portanto, a estratégia de usar a Internet como 
mais um canal de contato com o cliente tem sido pouco utilizada pelos hotéis de Brasília. O foco principal gira em torno da promoção e das vendas.

A principal vantagem do uso da Internet, do ponto de vista dos hotéis, é a agilidade que ela proporciona. Outras vantagens foram citadas pelos hotéis:

\begin{tabular}{l|l}
\hline TABELA 1 - VANTAGENS OBTIDAS COM O USO DA INTERNET \\
\hline Rapidez/ Agilidade & $61,5 \%$ \\
Redução de Custo & $53,8 \%$ \\
Melhor mensuração das campanhas & $23 \%$ \\
Maior visibilidade no mercado & $15,3 \%$ \\
Melhor atendimento & $15,3 \%$ \\
Aumento das vendas & $7,7 \%$ \\
Segurança & $7,7 \%$ \\
Diminui as distâncias & $7,7 \%$ \\
\hline
\end{tabular}

Todos os hotéis entrevistados avaliaram o uso da Internet como estratégia de marketing de forma positiva. A fim de ilustrar segue abaixo a transcrição de algumas respostas:

“A Internet é uma ferramenta indispensável pra qualquer segmento, especialmente para o mercado de turismo que as pessoas utilizam muito”. (Hotel Mercure)

"A Internet é uma das ferramentas ágeis, que você pode usufruir de forma benéfica” (Hotel St. Paul) 
"Avalio o uso da Internet de forma positiva, porque através dela se consegue, de forma rápida, disponibilizar informações para diversas partes do mundo".(Academia de Tênis)

“A Internet é fundamental, e a maioria dos hotéis que não estiverem preparados para a Internet não vão existir, vão ficar obsoletos, desconhecidos”. (Carlton Hotel)

Apesar, de todos os entrevistados julgar positivo o uso da Internet, alguns citaram algumas desvantagens, conforme a tabela abaixo:

\section{TABELA 2 - DESVANTAGENS DO USO DA INTERNET}

Falta de segurança

$30,7 \%$

Meio de comunicação frio (de pouco 15,3\% contato)

Problemas de conexão $7,7 \%$

Alto custo $7,7 \%$

Não há desvantagens $38,4 \%$

Entre as ferramentas da Internet usadas no relacionamento com os clientes, encontramse: website, e-mail e banco de dados. Todos os hotéis entrevistados utilizam estes instrumentos, porém não são todos que os empregam como ferramenta de marketing de relacionamento.

Conforme exposto na parte teórica, o uso de quadro de avisos eletrônicos, grupos de discussão, clubes on-line, formulários de avaliação e atendimento on-line são formas de aplicação do marketing de relacionamento no ambiente da Internet. A pesquisa revelou que muitos hotéis ou não usam nenhuma dessas formas ou usam apenas uma. 


\begin{tabular}{ll}
\hline TABELA 3 - FORMAS DE APLICAÇÃO DO MARKETING DE \\
RELACIONAMENTO NOS SITES DOS HOTÉIS \\
\hline Quadros de avisos eletrônicos/informativos & $38,4 \%$ \\
\hline Espaço para sugestões e comentários & $23 \%$ \\
\hline Formulários de avaliação & $15,3 \%$ \\
\hline Clubes on-line & $7,6 \%$ \\
\hline Atendimento ao cliente on-line & $7,6 \%$ \\
\hline Grupos de discussões & $0 \%$ \\
\hline Nenhuma & $46,1 \%$ \\
\hline
\end{tabular}

Ao analisar os sites dos hotéis escolhidos, observou-se grande preocupação com a promoção e a divulgação do hotel nesse novo mercado. Alguns hotéis não possuem uma estratégia clara ao usar a Internet, fizeram uma página na web apenas para afirmarem estar no mercado da Internet. Outros, a utilizam, exclusivamente para promover seus produtos e serviços, através de fotos.

Muitos entrevistados responderam que não utilizam os instrumentos do marketing eletrônico que exercem a função de interatividade, o que mostra que os hotéis de Brasília ainda não despertaram para a possibilidade de usar as suas páginas da Internet não só para promover e vender, mas também para estar em contato com seu público.

Foi verificado, também, que os poucos hotéis que já usam os seus sites para interagir com seus clientes são hotéis pertencentes a grandes redes. Estes, normalmente, possuem em seus sites mais de uma forma de aplicação do marketing de relacionamento.

Quanto ao uso do e-mail, foram obtidos os seguintes resultados: 


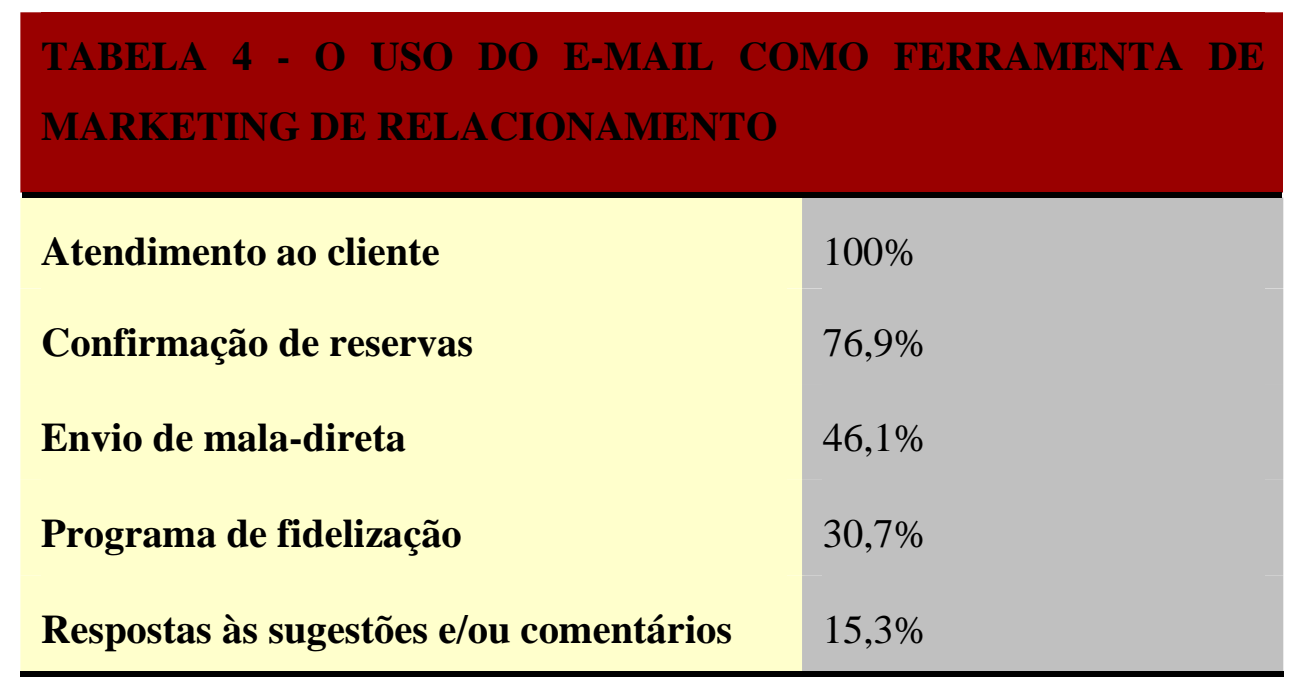

Os resultados mostram que o e-mail é a ferramenta do marketing eletrônico mais usada para a interação dos hotéis com seus clientes. Todos os entrevistados usam pelo menos uma dessas maneiras de ter contato com o seu público através do e-mail.

No uso do e-mail, notou-se que já existe uma preocupação maior com o relacionamento com o cliente. Muitos usam o e-mail como estratégia de manutenção e fidelização do cliente. Segue algumas afirmações dos responsáveis pelo marketing dos hotéis que evidenciam tal emprego do e-mail:

"Eventualmente usamos o e-mail para enviar promoções, a gente usa mais pra parabenizar um cliente que está fazendo aniversário, mandar uma mensagem...”

“A gente só trabalha por e-mail. È uma ferramenta indispensável”.

“A gente tem uma pesquisa de satisfação que é entregue para todo cliente no balcão no check-out, ele preenche e são enviados para os departamentos..., cada reclamação que eu veja que é importante, que é relevante, eu mesma respondo através do e-mail que ele coloca na pesquisa”.

No que se refere ao uso do banco de dados, praticamente todos os hotéis possuem o seu. No entanto observou-se que apenas $46,1 \%$ usam a Internet como meio de obtenção de 
informações sobre os clientes e suas preferências. Na maioria dos casos, não há uma interação dos sistemas internos, impossibilitando uma boa troca de informações, o que acarreta em um mau uso dessas.

Porém, já existe uma preocupação nesse sentido. Já existe uma conscientização de que a Internet contribui para a formação e atualização dos bancos de dados dos hotéis. "No novo site, a gente quer fazer um banco de dados(...), tem algumas promoções que você faz via Internet que podem te dar um banco de dados gigantesco em dois dias”, afirma a gerente de marketing do hotel Kubitscheck Plaza.. 


\section{CAPÍTULO 5 - CONSIDERAÇÕES FINAIS}

O uso da Internet no setor hoteleiro é indispensável para a empresa que pretende se manter no mercado competitivo. Suas características atenuam os problemas comuns no setor hoteleiro, como a tangibilidade e a sazonalidade. Além disso, foram identificadas várias vantagens obtidas pelos hotéis ao usarem a Internet: maior rapidez no atendimento, diminuição da distância entre a empresa e seu público-alvo, redução de custos, maior visibilidade no mercado, melhor mensuração das campanhas promocionais e aumento das vendas. É, também, um instrumento que pode ser usado com diversas finalidades, como: promoção, comércio e relacionamento com os clientes. É, portanto uma ferramenta valiosa para os hotéis, pois reduz os custos, possibilita a redução de problemas advindos das características do setor hoteleiro e amplia as opções de aplicação do marketing da empresa.

O estudo também verificou que a Internet consiste em um diferencial para o setor hoteleiro, em um algo mais para as empresas. Trata-se de uma ferramenta que vem a acrescentar às estratégias tradicionais do marketing da empresa. Ou seja, que o hotel pode, por exemplo, ampliar sua estratégia de marketing de relacionamento, usando além das ações tradicionais, como um bom atendimento na recepção e a personalização nos demais serviços prestados ao cliente durante sua hospedagem, usar o e-mail para parabenizar o cliente no seu aniversário, enviar um convite que se julga interessante para o cliente ou informá-los das novidades adotadas pelo hotel.

Assim como o e-mail, o uso do site amplia as ações de promoção, em que novas formas de divulgação são utilizadas pelo hotel, como a utilização de fotos em $360^{\circ}$ graus, vídeo institucional e banners eletrônicos, que atingem todos os públicos da empresa, já que essa é uma das características da Internet. Portanto, pode-se dizer que o uso de páginas eletrônicas é um complemento das promoções realizadas em revistas especializadas, em tv ou folder. Ou, pelo menos é mais uma opção para o hotel realizar a divulgação de seus produtos e serviços. Cabe, lembrar que o site ainda exerce as funções de informar, interagir com clientes e colher dados. 
Com relação ao uso da Internet como instrumento de interação entre os hotéis e seus clientes, constatou-se que existem muitas formas de aplicação do marketing eletrônico nesse sentido. De acordo com a pesquisa realizada no setor hoteleiro de Brasília, concluiu-se que a utilização desses recursos ainda é pequena, porém alguns hotéis já estão utilizando. O principal recurso utilizado pelos hotéis para se relacionarem com os seus hóspedes tem sido o e-mail, devido a sua característica de ser, entre os instrumento do marketing eletrônico, o mais pessoal.

Como conclusão da pesquisa de campo, foi identificado que o setor hoteleiro de Brasília, ainda não enxerga o uso da Internet como uma forma inovadora de interagir com seus clientes. O foco principal ainda está na promoção e no comércio. Dentre os objetivos do uso da Internet apontados pelos os entrevistados, o que obteve menor índice foi justamente o que se refere ao relacionamento com os clientes. E, a segunda finalidade menos citada foi a redução de custos. Assim, em contradição á hipótese sugerida, o setor hoteleiro de Brasília usa a Internet, principalmente, como estratégia de promoção.

Também verificou-se que poucos são os hotéis que se utilizam da Internet para expandir o seu banco de dados de clientes. Muitos já conhecem essa possibilidade, no entanto apresentam problemas internos que impedem a sua realização, como por exemplo, a falta de uma estrutura integrada dos sistemas de informação adotados na empresa.

Em suma, a Internet é um canal de fortalecimento do marketing estratégico na hotelaria, servindo de complemento ás demais ações. Esse é o seu principal e mais importante papel dentro do mercado hoteleiro. Tendo base nessa premissa, cada hotel pode estabelecer qual a sua principal estratégia ou até mesmo adotar várias ao mesmo tempo. A estratégia de usá-la para interagir com os clientes existe e possui muitas técnicas, no entanto ainda é pouco utilizada. 


\section{REFERÊNCIAS BIBLIOGRÁFICAS}

1. BEKIN, Saul Faingauss. Conversando sobre endomarketing. Um ciclo de entrevistas com Saul Bekin. 10 ed. São Paulo: Makron Books Brasil,1995.

2. COBRA, Marcos. Marketing de Turismo. São Paulo: Cobra, 2001.

3. COOPER, Chris;FLETCHER, John; WANHILL, Stephen; GILBERT, David; SHEPHERD, Rebecca. Turismo: princípios e prática. 2 ed. Porto Alegre: Bookman, 2001.

4. CUNHA, Licínio. Economia e Política do Turismo. Lisboa: Mcgraw-Hill, 1997.

5. GRONROOS, Christian. Marketing gerenciamento e serviços. São Paulo: Campus, 1995.

6. JANAL, Daniel. Como fazer marketing na Internet. 2 ed. Rio de janeiro: Infobook, 1996.

7. KOTLER, Philip. Marketing. São Paulo: Atlas, 1980.

8. KOTLER, Philip. Marketing para o século XXI. 9 ed. São Paulo: Futura, 2001.

9. KOTLER, Philip. Princípios de marketing. Rio de Janeiro: Prentice-Hall, 1993.

10. KUAZAQUI, Edmir. Marketing turístico e de hospitalidade. São Paulo: Makron Books, 2000.

11. LAGE, Beatriz Helena Gelas; MILONE, Paulo César. Turismo: teoria e prática. São Paulo: Atlas, 2000.

12. LARA, Simone B. Marketing e vendas na hotelaria. 2.ed. São Paulo: Futura, 2001.

13. MEDLIK, S. e INGRAM, H. Introdução à hotelaria: Gerenciamento e serviços. 4 ed. Rio de Janeiro: Campus, 2002.

14. MIDDLETON, Victor T. C. Marketing de turismo - teoria e prática. 3 ed. Rio de Janeiro: Campus, 2001.

15. NASH, Edward. Database marketing - Ferramenta atual e decisiva do marketing. São Paulo: Makron Books, 1994. 
16. O’CONNOR, Peter. Distribuição da informação eletrônica em Turismo e Hotelaria. Porto Alegre: Bookman, 2001.

17. ORGANIZAÇÃO MUNDIAL DE TURISMO. E-business para turismo. Porto Alegre: Bookman, 2003.

18. PETROCCHI, Mário. Hotelaria - Planejamento e gestão. 2 ed. São Paulo: Futura, 2002.

19. SILVA, Carlos José. Teoria de marketing. Apostila do Centro de Excelência em Turismo da universidade de Brasília, Julho, 2003.

20. STERNE, Jim e PRIORE, Anthony. E-mail marketing - Utilizando o e-mail para atingir seu público-alvo, conquistar e manter clientes fiéis. São Paulo: Makron Books, 2002.

21. STERNE, Jim. Marketing na web - Integrando a web à sua estratégia de marketing. 2 ed. Rio de Janeiro: Campus, 2000.

22. VERGARA, Sylvia Constant. Projetos e relatórios de pesquisa em Administração. 4 ed. São Paulo: Atlas, 2003. 


\section{APÊNDICE - ANÁLISE DE WEBSITES DOS HOTÉIS}

Com o objetivo de complementar à pesquisa de campo, foi feita uma análise dos sites dos hotéis onde ocorreram as entrevistas. Por se tratar de um instrumento que tem trazido um crescimento para o turismo, julgou-se importante analisá-lo detalhadamente. Foram analisados os sites sob vários aspectos, no entanto, o principal enfoque foi o relacionamento com os clientes. Fez-se uma descrição geral do site em termos de apresentação e identificaram-se as técnicas do marketing eletrônico usadas para atrair, manter e fidelizar clientes.

\section{HOTEL KUBITSCHEK PLAZA}

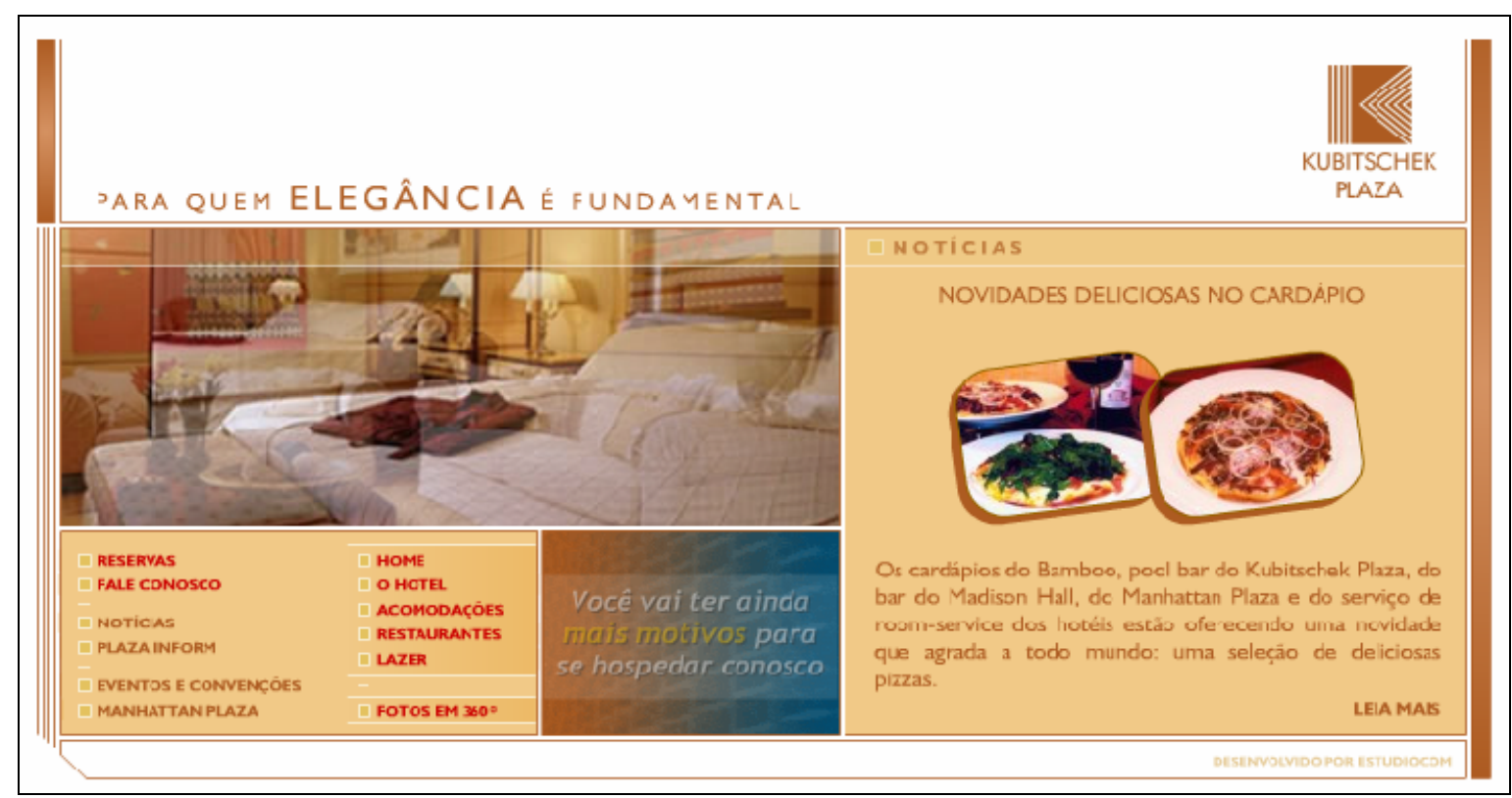

Site do Hotel Kubitschek Plaza - http: // www. Kubitschek.com.br

Trata-se de um site bem-estruturado, com utilização de menus permitindo fácil utilização por parte do usuário.

Com relação ao marketing de relacionamento, coloca à disposição dos usuários um serviço de atendimento ao cliente via telefone, como também, um atendimento através do email, em que apresenta o nome e o e-mail do responsável por cada setor do hotel. 
Como forma de obtenção de dados utiliza apenas o sistema de reservas on-line, em que o usuário registra, exclusivamente, seus dados cadastrais.

Há, ainda, o uso de vídeo na demonstração das suítes do hotel e fotos, como estratégias de promoção.

Portanto, o site do hotel Kubitscheck Plaza está mais direcionado à divulgação da empresa no mercado on-line e à venda de seus serviços. Interagir com o cliente não foi o objetivo da criação do site. Não há espaços destinados à captação de informações do cliente, como local onde o cliente possa dar sugestões, realização de pesquisa ou um atendimento online.

\section{MANHATTAN PLAZA HOTEL}

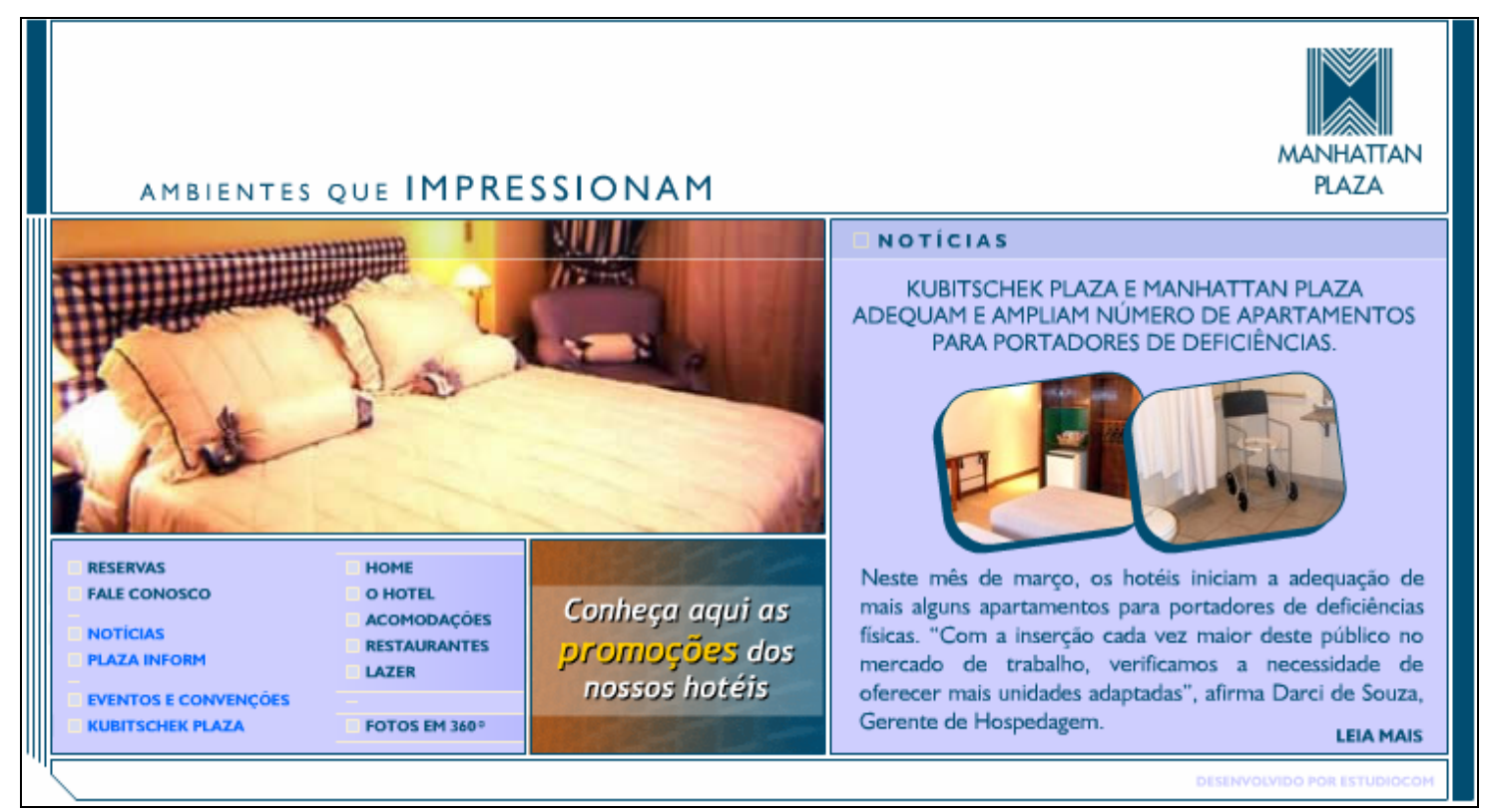

Site do Manhattan Plaza - http://www.manhattan.com.br

O Manhttan Plaza Hotel, por fazer parte da mesma empresa do Kubitscheck Plaza, possui um site praticamente idêntico, com a mesma estrutura, design e tipo de informações. 


\section{GRAND BITTAR HOTEL}

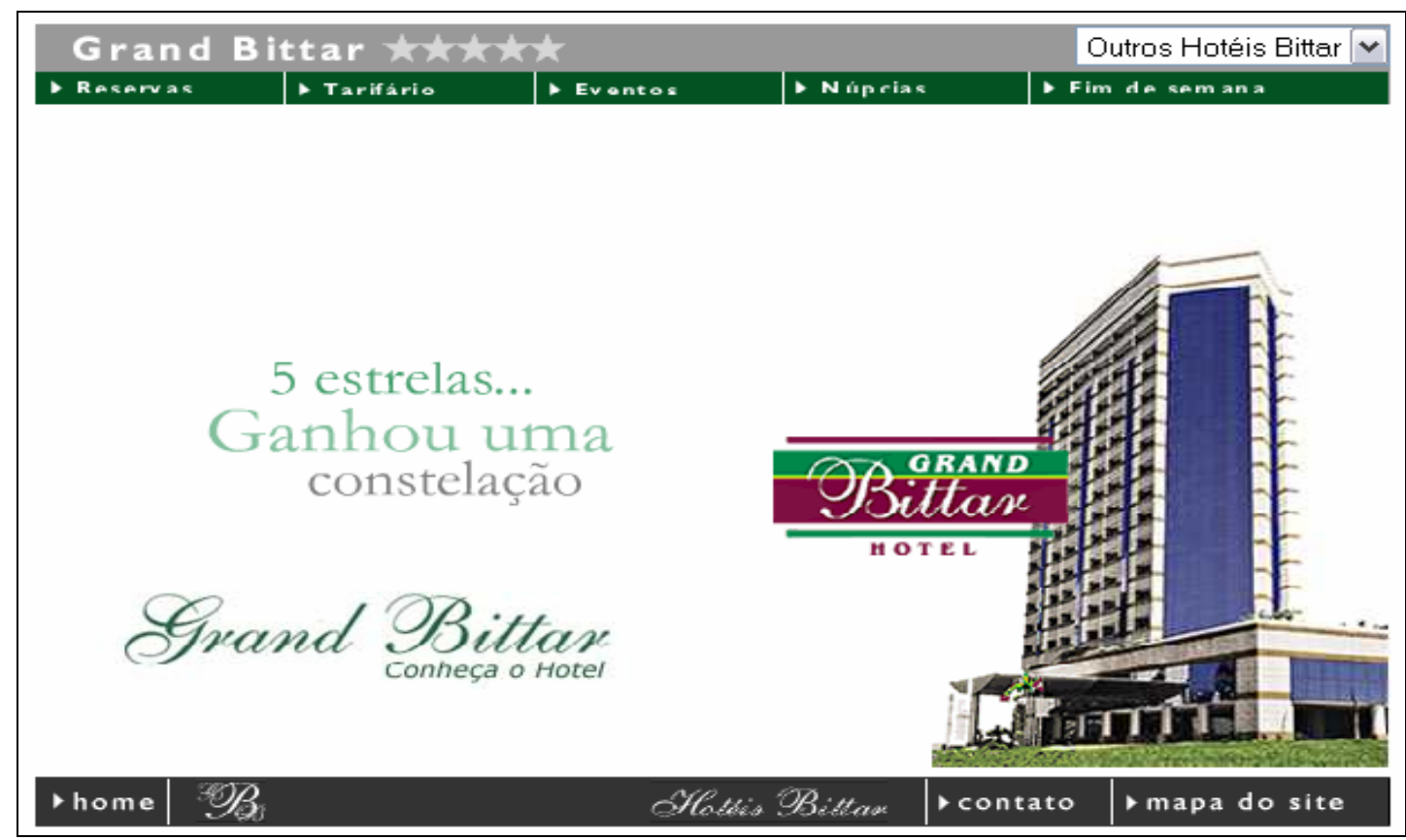

Site do Grand Bittar Hotel - http:// www.hoteisbittar.com.br

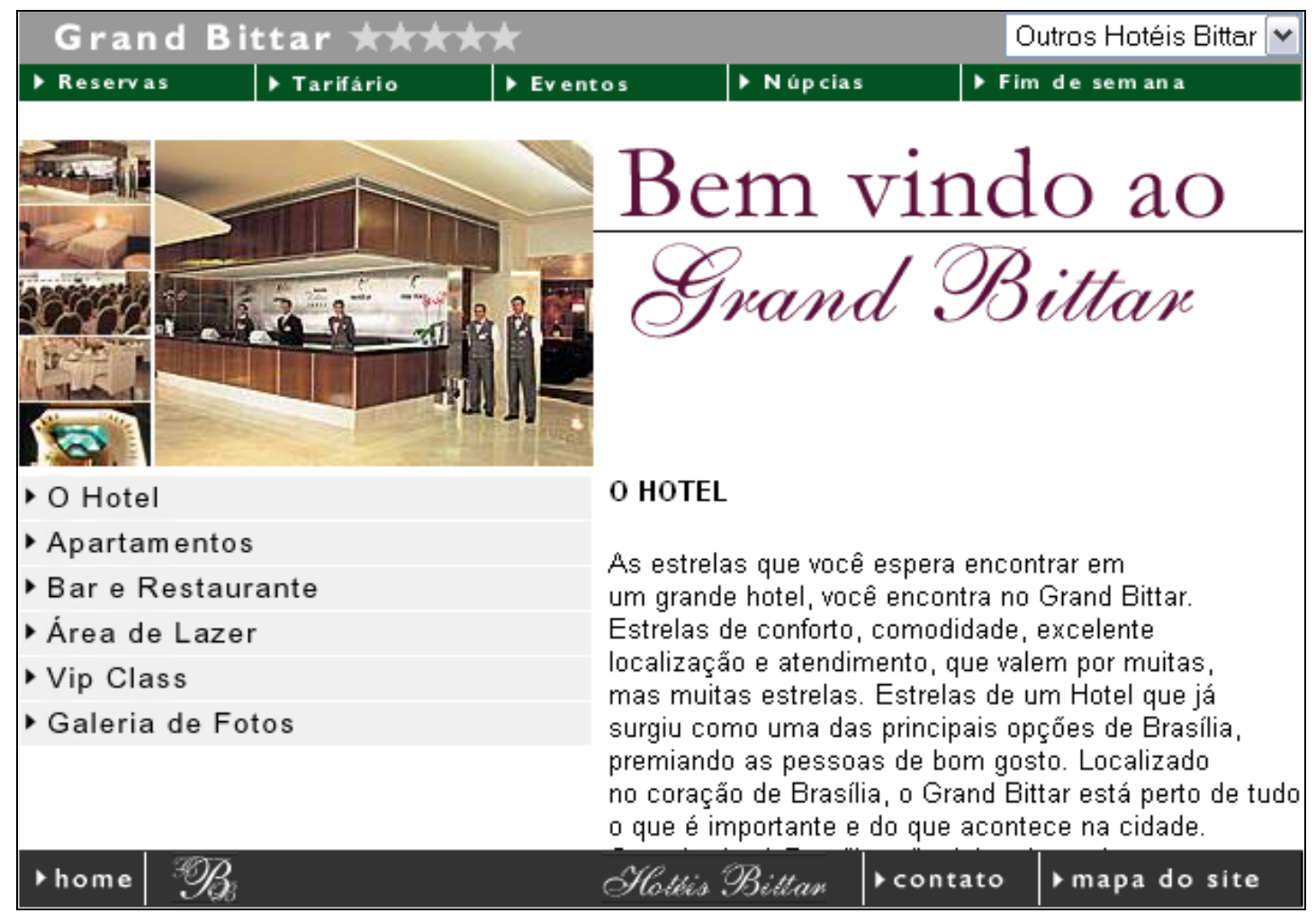


O Grand Bittar Hotel apresenta um site muito simples, de fácil utilização, porém sem muitos recursos atrativos. Dispõe suas informações através de menus.

Utiliza o atendimento ao cliente via e-mail, além do tradicional contato telefônico.

Como forma de obtenção de dados usa, unicamente, o serviço de reservas.

Em termos de instrumentos de promoção, dispõe apenas de fotos de seus ambientes.

\section{HOTEL PHENÍCIA}

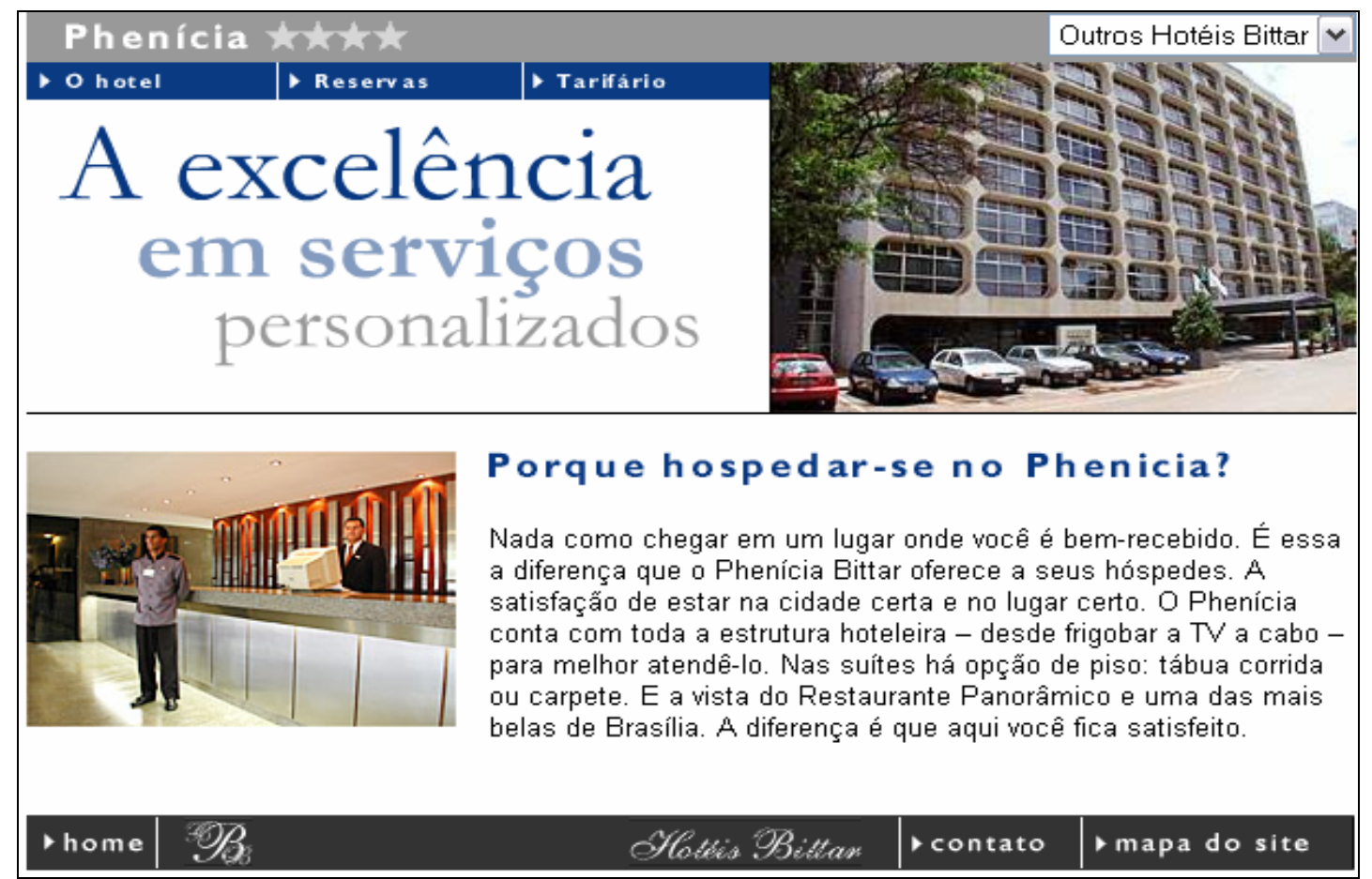

Site do Phenícia Bittar Hotel - http:// www.hoteisbittar.com.br

O site do Hotel Phenícia, assim como o do Hotel Grand Bittar - hotéis da mesma rede - apresenta-se simples. Utiliza-se também de submenus, no entanto a apresentação destes é menos sofisticada e para se ter acesso a eles é necessário abrir outra página, retardando o processo de navegação.

No restante, possui as mesmas características do Grand Bittar Hotel: 
- Presença do e-mail como instrumento de marketing de relacionamento na Internet;

- Tem como modo de coleta de dados dos clientes através do sistema de reservas;

- E como atrativo promocional utiliza-se da exposição de fotos dos ambientes do hotel.

\section{HOTEL ST. PAUL}



Site do St. Paul Park Hotel - http:// www.hotelstpaul.com.br

O hotel St. Paul possui um site bem estruturado, onde todos os menus estão dispostos na página principal e ao acessar um deles o menu continua visível, facilitando ainda mais a utilização e a rapidez.

Relativo às ferramentas de marketing de relacionamento utilizadas no site, tem-se:

- O contato via e-mail, além do atendimento pelo telefone.

- Seu sistema de reservas on-line coleta informações dos clientes além de seus dados cadastrais. É realizado através de uma empresa especializada na informatização de 
hotéis que mantém um banco de dados dos clientes bem personalizado. Tal coleta depende do cliente associar-se. A coleta de dados é realizada com a autorização do cliente e utiliza-se de instrumentos como pesquisa, analisando as preferências do cliente no momento em que este faz o seu roteiro de viagem e promoções via e-mail.

Quanto às formas de atrativos promocionais, utiliza-se basicamente de fotos.

\section{COMFORT SUITES BRASÍLIA}

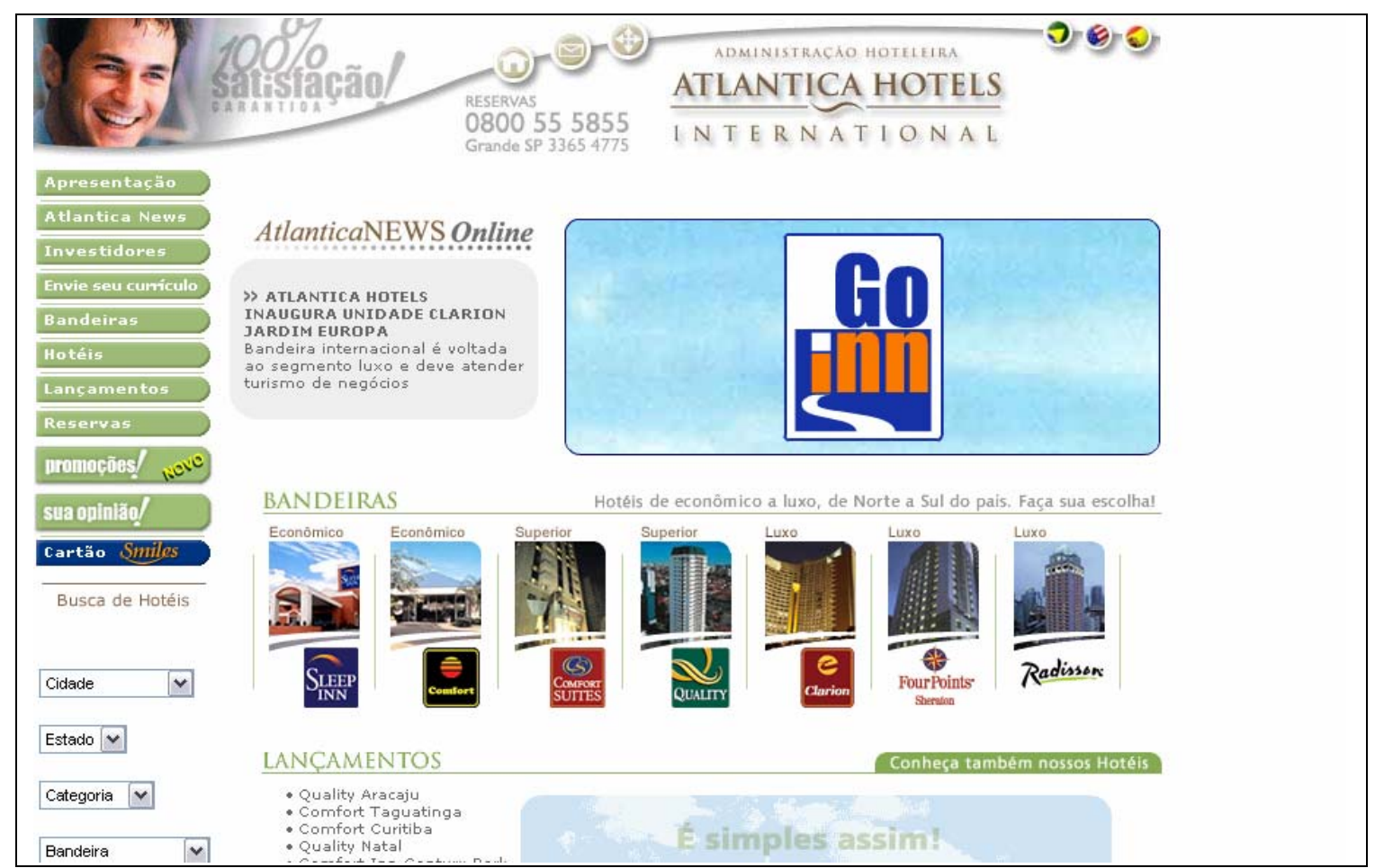

Site da Rede de hotéis Atlantica - http:// www.atlantica-hotels.com.br 


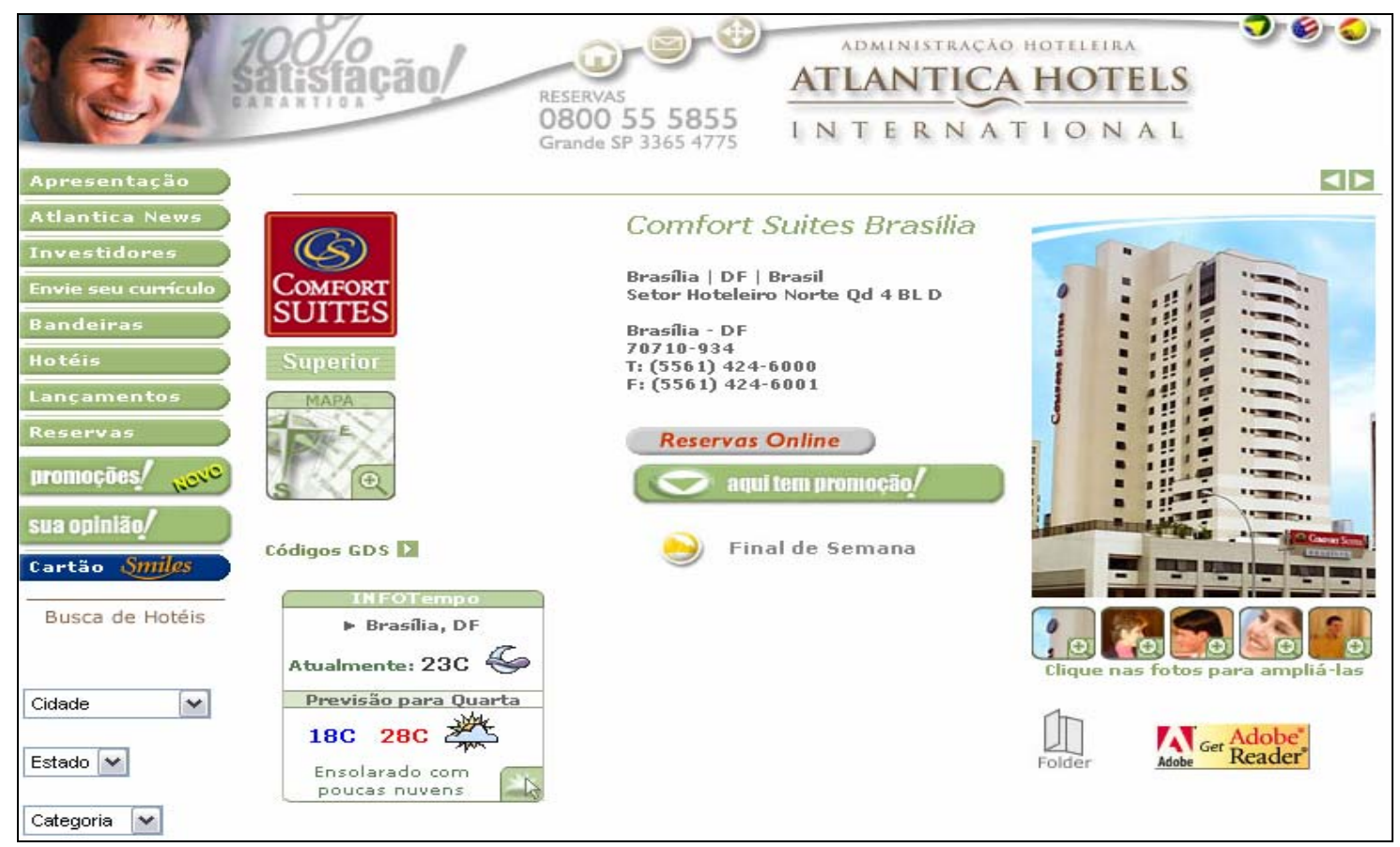

Site do Comfort Suítes Brasília - http:// www.atlantica-hotels.com.br

Por pertencer à rede de hotéis Atlântica, inicialmente tem-se acesso ao site da rede e através deste encontra-se o site do Comfort Suítes Brasília.

Analisando o site da rede, percebe-se que se trata de um site completo, bem estruturado e com diversas ferramentas de marketing. Possui uma estrutura simples e de fácil utilização, com menus sempre presentes, ainda que novas páginas sejam abertas.

Quanto às ferramentas de marketing encontra-se:

- Informativo on-line, onde as notícias da empresa estão sempre atualizadas.

- Utilização de vídeos na promoção

- Como meio de contato com o cliente, disponibiliza além do telefone, e-mail e fotos dos principais executivos da empresa e dos responsáveis pelos departamentos da empresa.

- Outro instrumento de interação com o cliente é o uso de um local que permite aos usuários opinar sobre sua estada e os serviços do hotel. Refere-se a um questionário, onde são feitas de três a cinco perguntas por serviço, entre a impressão geral que teve do hotel, os serviços e facilidades, o apartamento, o restaurante, e a equipe. 
No site específico do Comfort suítes Brasília acrescentam-se instrumentos promocionais como a disponibilização do folder do hotel e a utilização de fotos de seus ambientes. O sistema de reserva é o mesmo utilizado pelo hotel St. Paul - aquele realizado por uma empresa especializada em reservas e banco de dados. Como serviço adicional aos clientes são disponibilizadas informações referentes ao clima do local.

\section{HOTEL MERCURE}

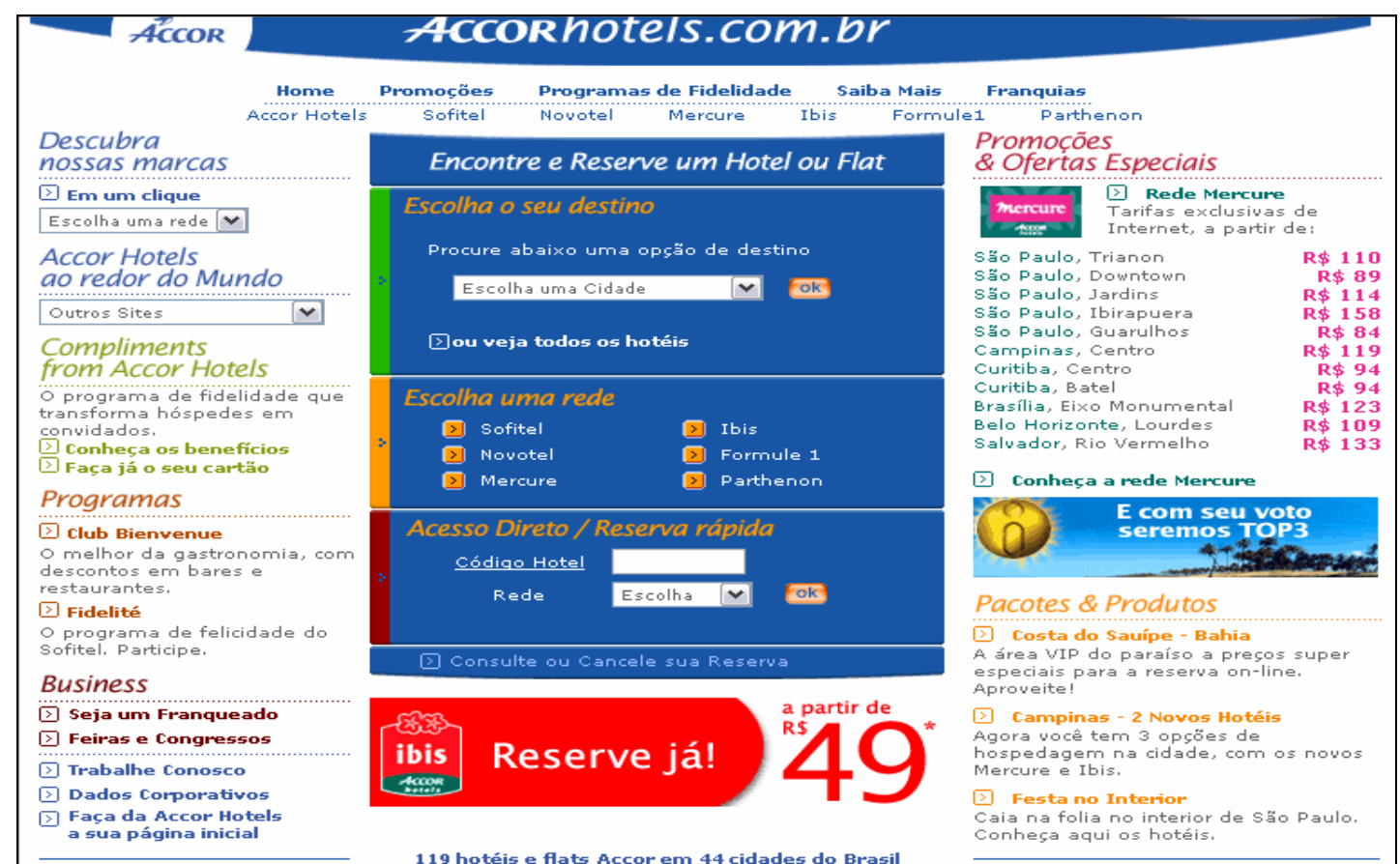

site do grupo Accor - http:// www.accorhotels.com.br 


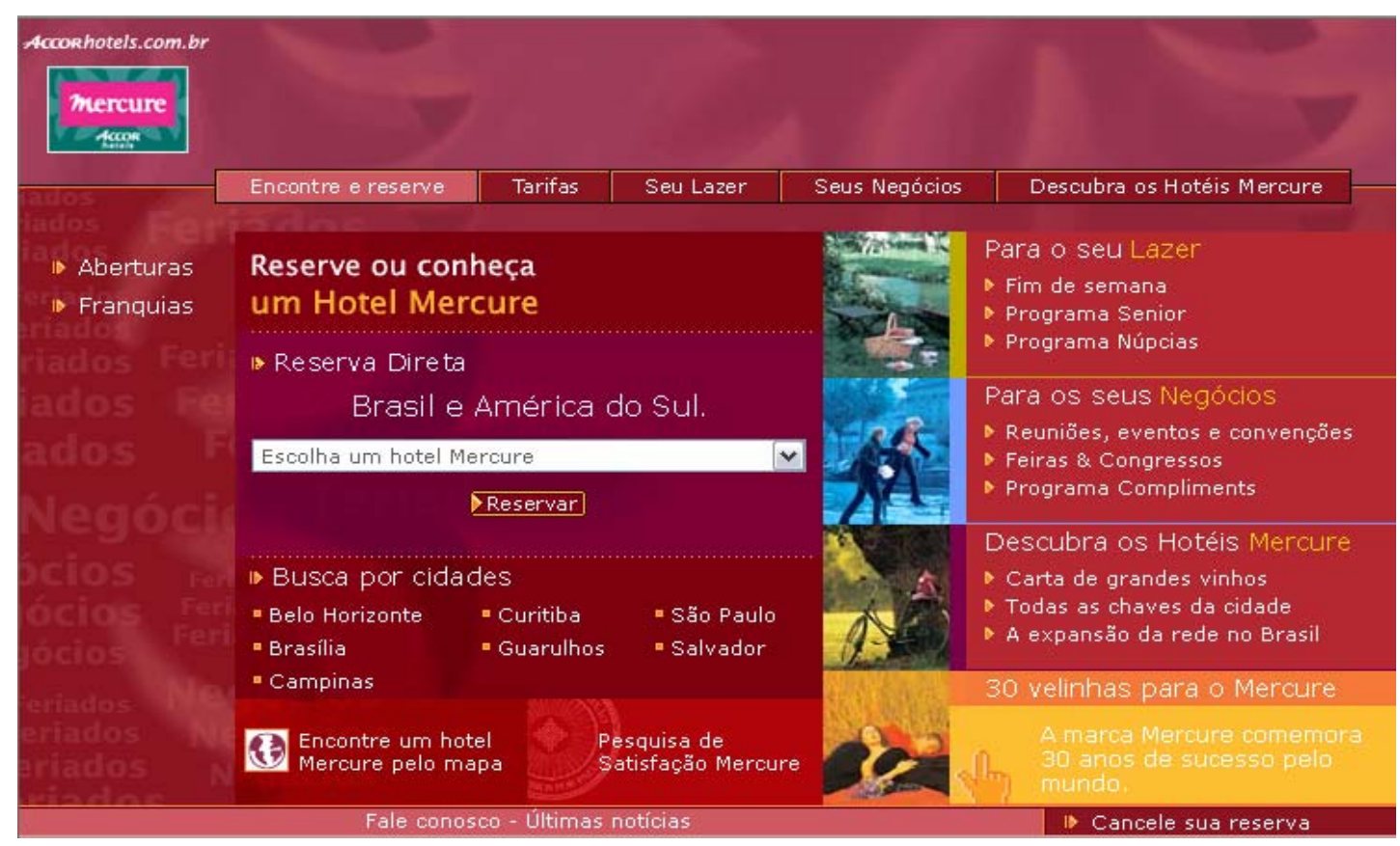

Site da Rede Mercure - http://www.accorhotels.com.br

O Hotel Mercure Brasília faz parte da rede de hotéis Mercure, que por sua vez pertence ao grupo Accor. O site divulgado pelo Hotel é o site da Accor e através deste pode-se ter acesso à rede Mercure e, conseqüentemente, ao site do Hotel Mercure Brasília.

O site do grupo Accor é completo e, apesar do grande número de informações, está bem estruturado. Na parte superior da página, utiliza o recurso de menus que ainda se subdividem em submenus.

No site do grupo Accor pode-se notar a preocupação que a empresa tem com o relacionamento com os clientes. Muitos são os recursos de marketing eletrônico usados para interagir com os clientes. Dentre eles estão: Serviço de atendimento on-line ao associado, espaço para sugestões e comentários, FAQ (dúvidas mais freqüentes), três programas de fidelidade - Compliments from Accor Hotels, que atende a todas as marcas do grupo; Programa Fidelité, da marca Sofitel; e Programa Club Bienvenue, que consiste em um programa de gastronomia das redes Sofitel, Novotel e Mercure, e que oferece benefícios aos associados nos restaurantes e bares da rede no Brasil. 
Analisando o site na rede Mercure, constatou-se que é um site com menos informações se comparado com o site da Accor, porém é organizado e de fácil utilização. Em completo aos recursos de marketing de relacionamento encontrados no site da Accor, o site da rede Mercure realiza pesquisa de satisfação dos clientes e possui uma agência de comunicação responsável pelo atendimento ao cliente através de correio eletrônico e telefone. A rede utiliza um dos grandes recursos proporcionados pela Internet, a divulgação através de imagens. Com um vídeo institucional a empresa se torna mais real para os clientes potenciais.

O site do Hotel Mercure Brasília é bastante simples e sem muitos instrumentos voltados para o relacionamento com os usuários, uma vez que estes estão dispostos no site do grupo Accor e da rede Mercure. Sua função está voltada para a realização das reservas.

\section{ERON BRASÍLIA HOTEL}

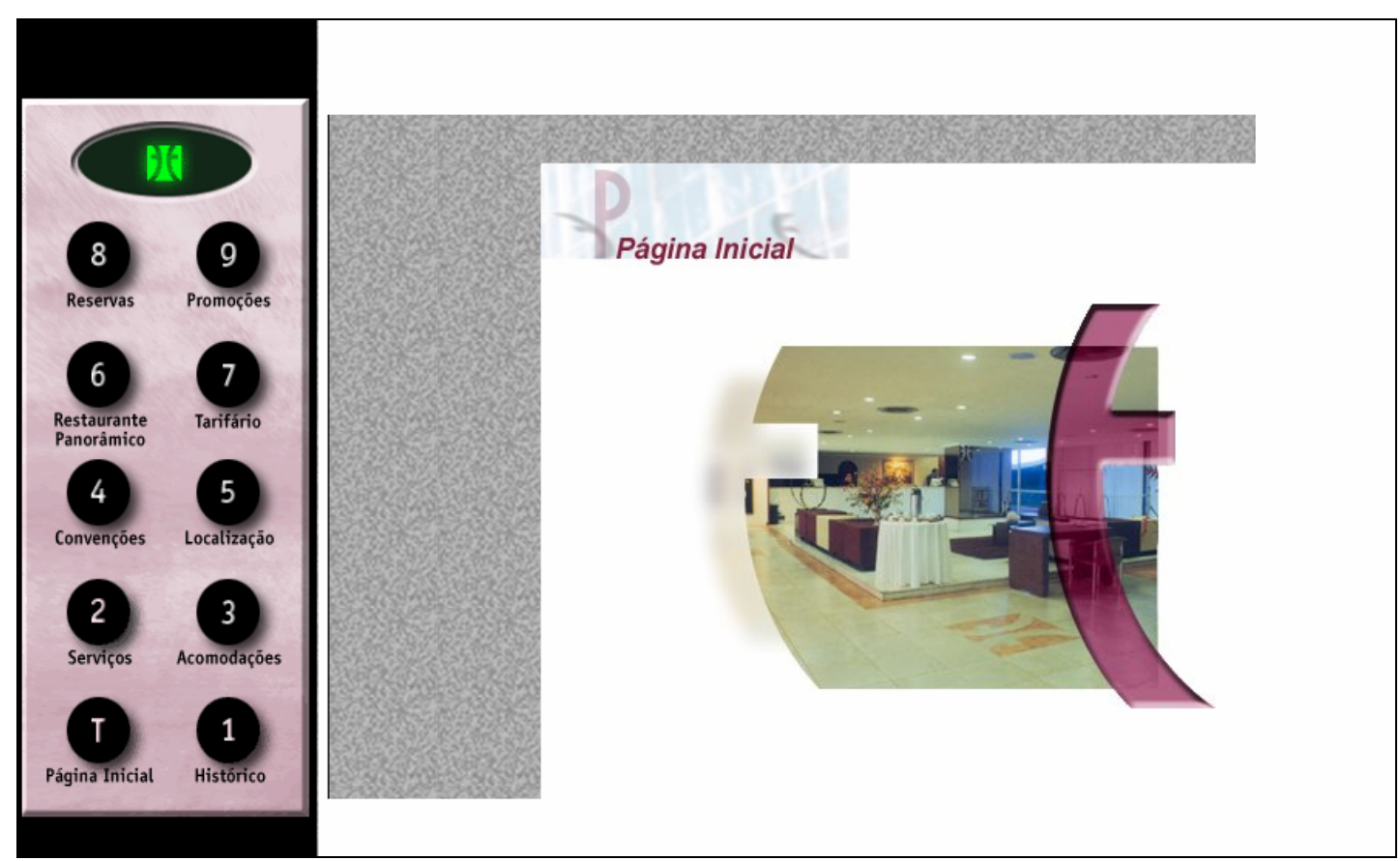

Site do Hotel Eron - http://www.eronhotel.com.br

A web site do Eron Hotel é simples, porém inovadora. Diferentemente dos outros hotéis sua estruturação é criativa. Os menus estão dispostos como um painel de elevador e as páginas 
acessadas através do menu apresentam fotografias sob a visualização da logomarca da empresa.

No que se refere ao marketing de relacionamento, não utiliza muitas ferramentas. O único local do site que permite algum tipo de relacionamento com o cliente é o de reservas. Ademais informa os e-mails de diversos departamentos, no entanto sem identificar seus responsáveis.

\section{ACADEMIA DE TÊNIS RESORT}

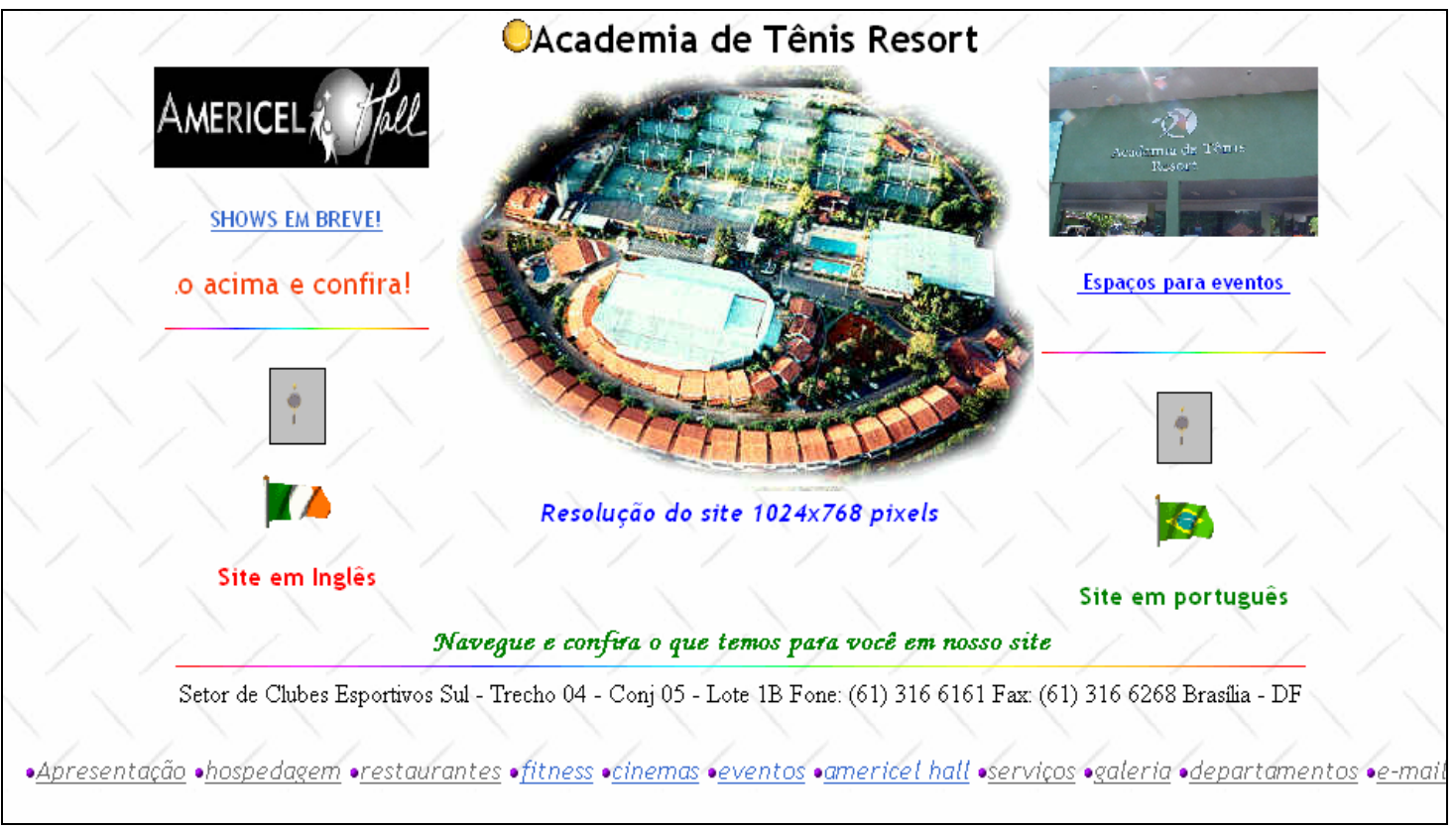

Site da Academia de Tênis - http://www.atr.df.com.br

O site da Academia de Tênis Resort é bastante fácil de se utilizar, apresentando uma estrutura simples.

Não há nenhuma estratégia de marketing de relacionamento presente no site. Os canais disponibilizados para os clientes são números de telefones e endereços de e-mails dos departamentos do hotel. 
10. CARLTON HOTEL

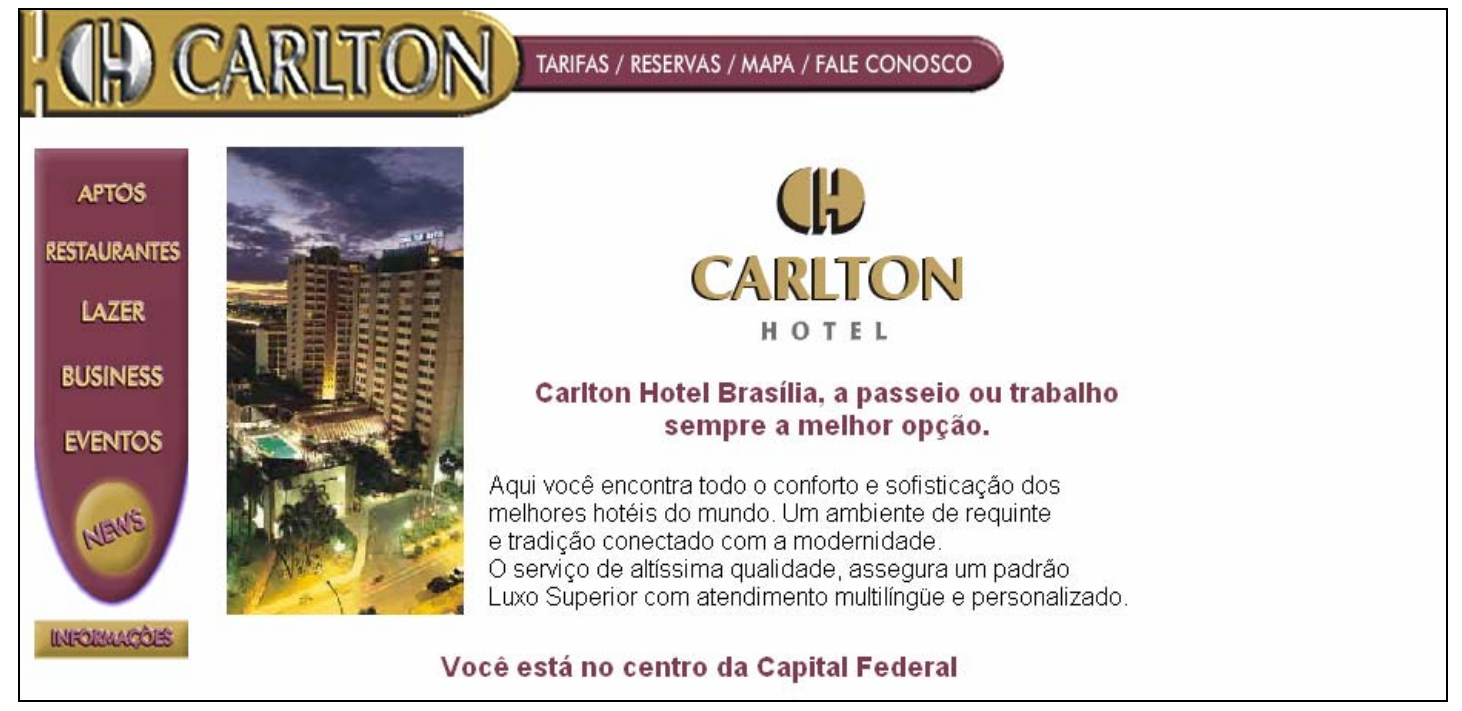

Site do carlton Hotel - http:// www.carltonhotel.com.br

O site do Carlton Hotel consiste em mais um canal de exposição da empresa no mercado da Internet. Como meio de relacionamento com os clientes só usa o sistema de reserva, em que ao final disponibiliza um espaço para sugestões.

Usa o site também para divulgar outra forma de interagir com os clientes, o correio eletrônico do hotel. 


\section{HOTEL ARACOARA}

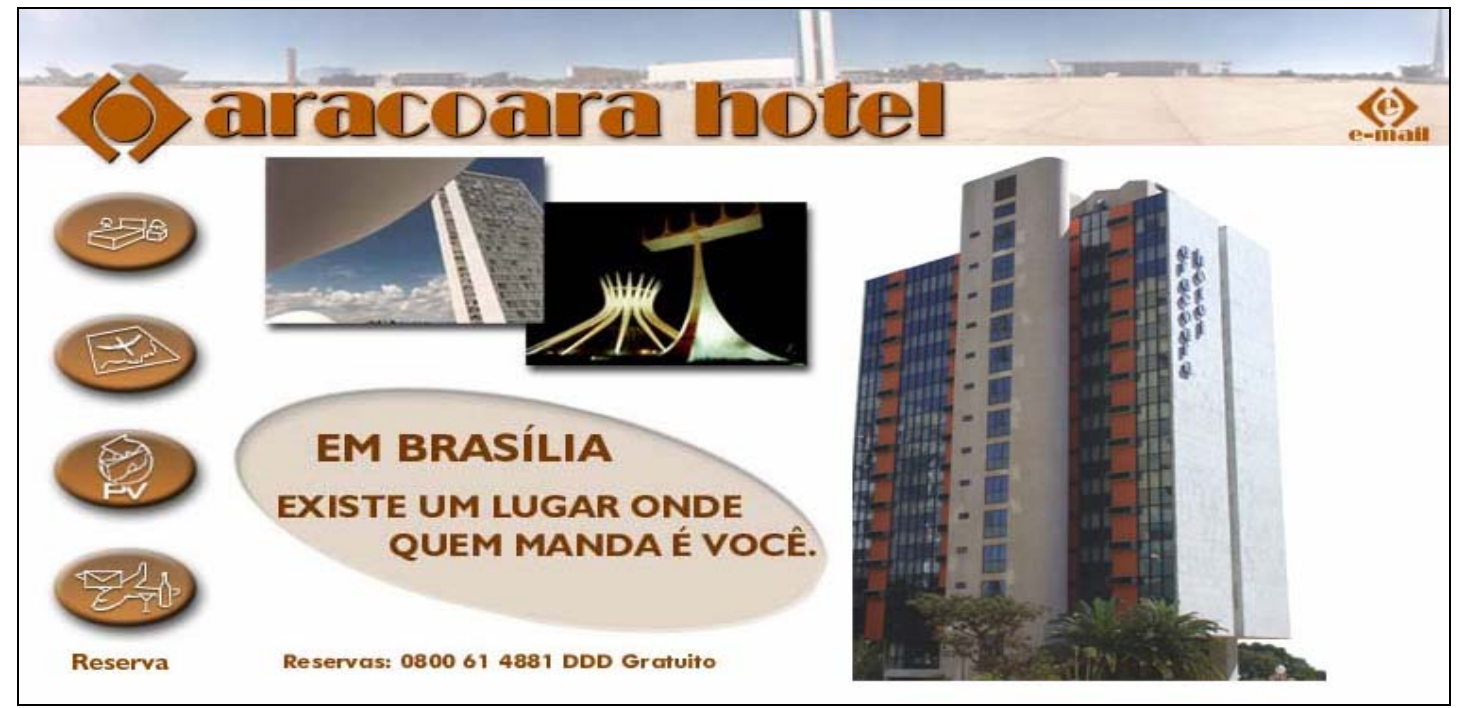

Site do Aracoara Hotel - http:// www.aracoara.com.br

Trata-se de um site com estrutura simples, cujas informações estão divididas em quatro menus.

A principal finalidade do site do hotel Aracoara é a promoção. Nenhuma ferramenta de marketing de relacionamento é utilizada no site, apenas um endereço de $e$-mail é colocado à disposição do cliente.

O site oferece, ainda, informações sobre pontos turísticos de Brasília e um mapa interativo da cidade. 


\section{HOTEL NACIONAL}

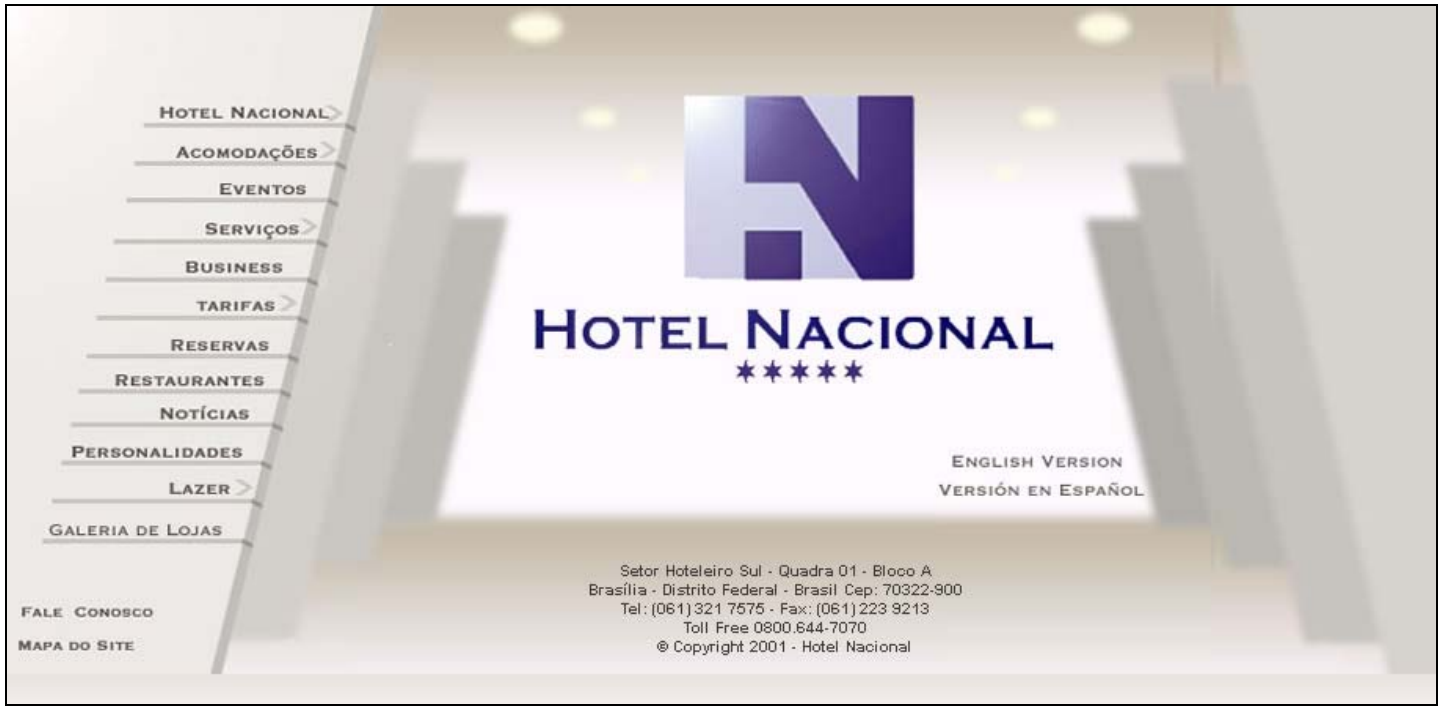

Site do Hotel Nacional - http:// www.hotelnacional.com.br

Trata-se de um site com estruturação simples e com suas informações divididas em menus e submenus.

No site não foi encontrado nenhum instrumento de marketing de relacionamento, apenas a divulgação de um endereço de $e$-mail.

Também, não utiliza o site para a coleta de informações dos clientes. 


\section{NAOUM PLAZA HOTEL}

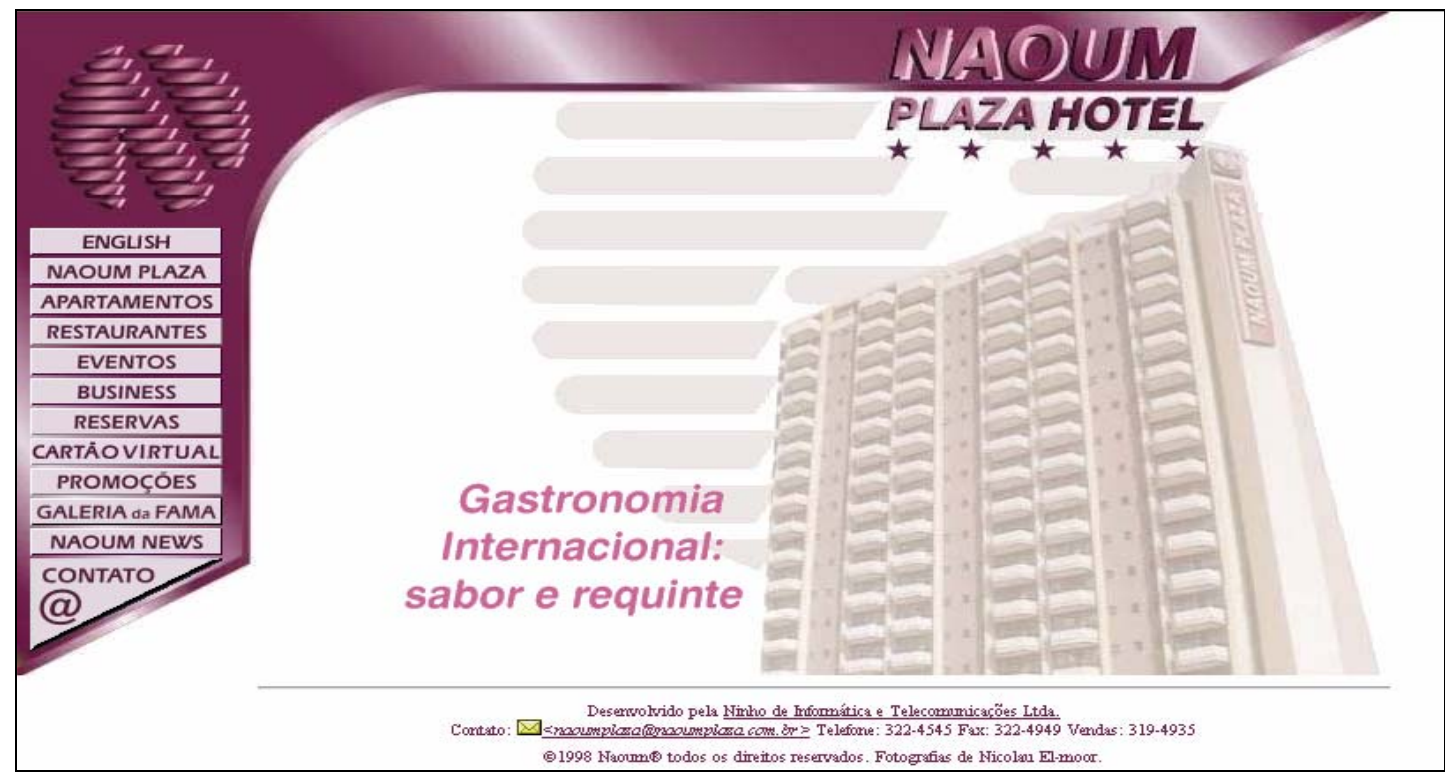

Site do Naoum Plaza Hotel - http:// www.naoumplaza.com.br

O hotel Naoum Plaza possui uma página eletrônica com uma estrutura muito boa, fácil de usar e subdividida em menus na lateral. Além disso, o seu conteúdo informativo é bastante claro e completo.

O site utiliza estratégia de promover e informar o cliente sobre seus produtos. Quanto às estratégias de marketing voltadas à interação com clientes, o hotel apenas possui um local para sugestões, comentários, em que as respostas são enviadas por $e$-mail.

\section{CONCLUSÃO DA ANÁLISE}

Os sites estão sendo utilizados principalmente para a divulgação e promoção dos hotéis. Existe uma preocupação com tecnologias visuais, ou seja, com a implantação de recursos que possibilitam cada vez mais mostrar a realidade do hotel. Encontrou-se o uso de fotos que permitem uma visão do ambiente de $360^{\circ}$ graus e hotéis maiores usando vídeos institucionais on-line. 
Poucos usam o site para interagir com seus clientes. Dos sites analisados, apenas dois usam mais de uma ferramenta do marketing eletrônico para estabelecer contato com os clientes. Portanto, a interatividade proporcionada pela Internet ainda não é explorada pelos hotéis. 